University of Nebraska - Lincoln

DigitalCommons@University of Nebraska - Lincoln

$2-25-2020$

\title{
The Effect of Child Support on Selection into Marriage and Fertility
}

Daniel Tannenbaum

Follow this and additional works at: https://digitalcommons.unl.edu/econfacpub

This Article is brought to you for free and open access by the Economics Department at DigitalCommons@University of Nebraska - Lincoln. It has been accepted for inclusion in Economics Department Faculty Publications by an authorized administrator of DigitalCommons@University of Nebraska - Lincoln. 


\title{
The Effect of Child Support on Selection into Marriage and Fertility
}

\author{
Daniel I. Tannenbaum, University of Nebraska
}

This paper studies the expansion of US child support policies from 1977 to 1992 and its consequences for marriage and fertility decisions. I develop a model showing that child support enforces ex ante commitment from men to provide financial support in the event of a child, which (1) increases premarital sex among couples unlikely to marry and (2) reduces the abortion rate by reducing the cost of childrearing to single moms. Using variation in the rollout relative to the timing of nonmarital pregnancy, I find that child support policies reduced the likelihood of marriage and reduced the abortion rate.

\section{Introduction}

Since the 1970s, the United States has dramatically strengthened the enforcement and collection of child support from nonresident parents. Beginning in 1975 with part D of the Social Security Act and continuing with

I thank Enghin Atalay, Marianne Bertrand, Pietro Biroli, Pierre-André Chiappori, Manasi Deshpande, Alex Frankel, Matthew Gentzkow, William Hubbard, David Jimenez-Gomez, Thibaut Lamadon, John List, Joaquin Lopez, Magne Mogstad, Kevin Murphy, Sebastian Sotelo, Adriaan Ten Kate, Alessandra Voena, and seminar participants at the University of Chicago, the University of Memphis, the University of Missouri, and the Society of Labor Economists for helpful comments and suggestions. Special thanks to Anne Case and Sara McLanahan for sharing the child support statute data and to Hannah Lazar for invaluable research assistance. Funding from a University of Chicago Social Sciences grant is gratefully acknowledged. Disclaimer: Any opinions and conclusions expressed herein are those of the author and do not necessarily represent the views of the US Census Bureau. All results have been reviewed to ensure that no confidential information is disclosed. Contact the corresponding author, Daniel I. Tannenbaum, at dtannenbaum@unl .edu. Information concerning access to the data used in this paper is available as supplemental material online.

[Journal of Labor Economics, 2020, vol. 38, no. 2]

(C) 2020 by The University of Chicago. All rights reserved. 0734-306X/2020/3802-0008 $\$ 10.00$

Submitted March 13, 2017; Accepted January 25, 2019; Electronically published February 25, 2020 
major legislation in the 1980s and 1990s, these statutes were enacted to protect children and ensure that nonresident parents, the majority of whom are male, share in the burden of child-rearing. ${ }^{1}$

Child support laws also have the potential to affect individual decisions regarding marriage and fertility. Child support laws ensure that mothers can receive financial support for child-rearing without having to marry the father; they also allow fathers to have a legal relationship with their child without marriage. In addition, child support laws increase the cost of fathering a child, particularly an unwanted child, and males may respond by reducing their fertility. Understanding the impact of child support laws on family structure is of critical importance, not least because dramatic changes in marital patterns have coincided with a period of rapid child support expansion (Stevenson and Wolfers 2007). To the extent that child support laws affect marital formation, they also affect the family structure in which children are reared, which may have consequences for their long-term chances of success (McLanahan and Sandefur 1994; Case, Lubotsky, and Paxson 2002; Bertrand and Pan 2013).

The analysis in this paper focuses on the marriage decision immediately following a nonmarital pregnancy, sometimes referred to as a "shotgun" marriage (Akerlof, Yellen, and Katz 1996). There are two reasons for focusing on this marriage decision. First, an influential paper by Akerlof, Yellen, and Katz (1996) finds that the decline of marriages following an out-ofwedlock pregnancy explains, in an accounting sense, the majority of the increase in out-of-wedlock births between 1965 and 1990. Second, these marriages are likely to be the most elastic with respect to child support laws: a couple with a pregnancy deciding whether to marry will consider what happens if they do not, a state of affairs governed directly by child support. Prior to the child support era, if such a couple decided against marriage, the child would have had no legal father. With a shotgun marriage, however, the husband was (and still is) granted the presumption of paternity (Edlund 2013), which was accompanied by custodial rights and financial obligations to support the child. ${ }^{2}$ Hence, unmarried couples facing a pregnancy face a direct and immediate trade-off among marriage, single motherhood, and aborting the

${ }^{1}$ To provide a benchmark sense of child support's reach and expansion, in fiscal year 2013 there were 15.6 million child support cases and $\$ 31.6$ billion of total distributed child support collections, compared with 4.1 million cases and $\$ 3.6$ billion in fiscal year 1978, valued in 2013 USD (source: Office of Child Support Enforcement [OCSE], FY2013 Preliminary Report, table P-52, and Solomon-Fears 2005). The majority of the increase in child support cases and collections has been among children of never-married couples rather than of divorced couples (Freeman and Waldfogel 2001).

${ }^{2}$ A marriage after the birth of the child would have established the father as a stepfather only, and if he desired to establish legal parental rights he would have had to go through legal proceedings to formally adopt the child. 
pregnancy. I explore these mechanisms with a theoretical model that illustrates how child support may crowd out the commitment role of marriage. ${ }^{3}$

In the empirical analysis of this paper, I first show that child support laws at the time of pregnancy have an effect on child support income receipt in subsequent years for mothers who do not marry. Using variation in the timing of pregnancy relative to the rollout of child support legislative enactments, I show that the full rollout of child support laws can account for around a 5 percentage point increase in the probability of a never-married mother receiving any child support income, off a base of $17 \%$. The mean dollar amount of child support received, conditional on receipt, is between $\$ 2,000$ and $\$ 3,000$ per year (expressed in 2000 USD) and represents about $10 \%-15 \%$ of annual household income for these families. This evidence is consistent with previous literature finding an effect of child support laws on the mother's income. ${ }^{4}$

Next, I consider the effect of child support laws on the marriage decision following a nonmarital pregnancy. The empirical design is motivated by the idea that the exact timing of conception relative to the child support legislative rollout is difficult for the individual to control. To consider the effect of child support on the marriage decision, I use variation in the spatial and temporal rollout of state child support laws relative to the timing of nonmarital pregnancy. The main specification assumes that propensity to marry evolves in the same way for women who are pregnant as it does for those who are not. This assumption is later relaxed by allowing first a linear time trend and then separate year interactions with pregnancy. I perform a variety of specification checks to demonstrate that the estimates are robust and are not driven by a violation of common trends. ${ }^{5}$ All specifications support

${ }^{3}$ Evaluating the welfare consequences of a child support policy for children requires an understanding of both the potential negative effects on family structure and the increased resources to single-parent households, an analysis that is beyond the scope of this paper.

${ }^{4}$ See, e.g., Beller and Graham (1991), Miller, Garfinkel, and McLanahan (1997), Argys, Peters, and Waldman (2001), Freeman and Waldfogel (2001), and Sorensen and Hill (2004).

${ }^{5}$ First, I show that baseline characteristics, including both outcome variables and controls, do not predict future innovations in child support laws, reducing the concern for reverse causality. Second, I control directly for societal attitudes at the region level, which proxy for public sentiment on issues including premarital sex, sex education, abortion, and the generosity of public assistance. Third, I show that the estimates are robust to specifications allowing for differential trends related to baseline state-level characteristics. Fourth, I allow the propensity to marry to vary flexibly with time separately by pregnancy state; the main effect remains similar in sign and magnitude but loses statistical significance. An $F$-test of the null hypothesis that the interactions between year dummies and pregnancy state are jointly equal to zero fails to reject, lending support to the main specification and mitigating concern that differential trends in the propensity to marry by pregnancy state are driving the results. 
the interpretation that child support has reduced the likelihood of couples marrying following a nonmarital pregnancy.

An important challenge for identification in this setting is selection: the main regression is estimated under the assumption that child support policies are not affecting female fertility differentially based on her underlying propensity to marry. It is plausible, for example, that child support discourages fertility among women who are most likely to marry. To explore this possibility, I estimate the direct effect of child support on fertility and find the estimates negative but small and insignificant, too small by an order of magnitude to explain the estimated effects on shotgun marriages. ${ }^{6} \mathrm{I}$ also perform pessimistic counterfactual exercises that assign higher and higher marriage rates to nonpregnancies and reestimate the main specification.

The regression estimates suggest that the full set of child support laws adopted by US states over this period reduced the probability of a marriage following a nonmarital pregnancy by about 7.7 percentage points, off a base of $38 \%$. This number is quite large compared with the total decline in the fraction of nonmarital pregnancies resolved in a marriage before birth, about 10 percentage points over the 1977-92 sample period for which the child support legislative data are available. These shotgun marriages represent about $10 \%$ of all first marriages, and hence this effect is a relatively minor change in marital patterns overall. However, the effect is large enough to have a substantial impact on nonmarital birth rates; a back-of-the-envelope calculation suggests that a decline in shotgun marriages of this magnitude can account for the fraction of nonmarital births increasing by about 2.7 percentage points, relative to its total increase of $11 \%$ over the sample period.?

Next I estimate the effect on the state-level abortion rate, which is defined as the number of abortions per 1,000 women aged 15-44 in a state-year. Child support may affect the abortion rate by lowering the cost of raising a child as a single mom. I show that the full set of child support laws reduced the abortion rate by 1 to 2 per 1,000 women, relative to a base of 28 . These

${ }^{6}$ Aizer and McLanahan (2006) find a negative effect on total fertility for those with a high school degree or less and slightly positive effects for those with some college or more. This finding works against finding a negative effect on shotgun marriages, however, since low-educated women are less likely to have a shotgun marriage than high-educated women. The theoretical model presented in sec. III supports their finding: those who are least likely to marry following a pregnancy reduce their fertility the most. Both pieces of evidence suggest that the estimates presented in this paper are a lower bound, in absolute value, of the true effect.

7 This calculation follows Akerlof, Yellen, and Katz (1996) and can be made as follows. Define the shotgun marriage rate as the fraction of couples who marry between pregnancy and birth. Then the change in the fraction of children born outside marriage due to a change in the shotgun marriage rate, holding the fraction conceived outside marriage fixed, is $\left(1-s_{t+1}\right) b_{t+1}-\left(1-s_{t}\right) b_{t+1}$, where $s_{t}$ represents the shotgun marriage rate at time $t$ and $b_{t+1}$ represents the fraction conceived outside marriage at time $t+1$. 
results again rely on the somewhat strong assumption of common trends, which will be violated, for example, if state-level trends in attitudes toward abortion and child support laws are correlated or jointly determined. For this reason I control directly for attitudes toward the legalization of abortion and the composition of state legislatures and governors' offices. In addition, I subject the estimates to the same battery of specification checks and robustness exercises as described above for the marriage estimates. The results hold up well.

This paper contributes to the literature studying long-term marital trends, including the decline of shotgun marriages (Akerlof, Yellen, and Katz 1996; Alesina and Giuliano 2006) and the rise of nonmarital births (Willis 1999). Akerlof, Yellen, and Katz (1996) document the decline in marriage following nonmarital pregnancies between 1965 and 1990 and show that this decline accounts for the majority of the increase in births to unmarried women over this period. Akerlof, Yellen, and Katz (1996) present a theory in which the availability of contraceptives and abortion can reduce shotgun marriages. This paper is complementary to their work, presenting both theoretical support and empirical evidence that child support is a key factor behind the dramatic decline in these marriages. ${ }^{8}$

Several studies find that child support laws have led to a decline in total nonmarital births (Case 1998; Aizer and McLanahan 2006; Plotnick et al. 2007); Rossin-Slater (2017), on the other hand, finds that the adoption of inhospital paternity establishment programs reduces postbirth parental marriage and hence increases nonmarital parentage. The theoretical model of this paper rationalizes these findings. I show that a decline in total nonmarital births can occur because men reduce fertility to avoid costly unwanted births. However, conditional on a pregnancy, marriage rates decline and the fraction of births that are born outside marriage increases. The empirical evidence presented in this paper is consistent with this unified interpretation.

This paper also contributes to the literature studying determinants of the abortion decision. Prior research has considered the role of the welfare system (Moffitt 1998), Medicaid funding (Henshaw et al. 2009), and legal restrictions on providers (Haas-Wilson 1996; Joyce and Kaestner 2000). This is the first paper, to my knowledge, to consider the effect of child support laws on abortion rates. Moreover, there is little work in economics attempting to understand the causes behind the decades-long decline in the abortion rate, which peaked in the early 1980 s at 29.3 abortions per 1,000 women aged 15-44 years but has subsequently declined to 19.6 as of 2008 (Jones

${ }^{8}$ An important distinction between the Akerlof, Yellen, and Katz (1996) model and the one presented in this paper is that Akerlof, Yellen, and Katz (1996) present the decline in shotgun marriages as welfare diminishing for marginal women who no longer marry, while here it is welfare enhancing for these women because they receive additional transfers outside marriage. 
and Kooistra 2011). This paper provides evidence that child support is an important factor.

The rest of the paper is organized as follows. Section II presents a brief overview of the child support process and describes the legislative data used in the empirical analysis. Section III presents a conceptual framework to explore mechanisms and consider welfare consequences. Section IV describes the data and presents summary statistics and empirical trends. Section V presents the identification strategy, the main results, and robustness exercises. And section VI concludes.

\section{Background on Child Support}

The first major federal policy affecting child support was the creation in 1975 of part D of Title IV of the Social Security Act, which created the federal OCSE. ${ }^{9}$ The primary purpose cited in these laws is twofold: to promote the best interests of the child by promoting financial stability within families and to decrease dependence on public assistance.

The child support process.-At the individual level, the child support process begins with paternity establishment. If the mother is married at the time of birth, the husband is presumed to be the father. If the mother is unmarried at the time of birth, the state or child support agency will attempt to determine paternity, according to the state laws in effect. There have been significant changes in the procedure for establishing paternity since the 1970s. In 1978, 111,000 paternities were established, increasing to 1.6 million in 1999 (Committee on Ways and Means 2014). ${ }^{10}$

If paternity is not established or presumed, a biological father has no rights or obligations to his child. From a legal perspective, the child and biological father are strangers. For centuries, governments and church parishes have attempted to reduce their welfare rolls by locating absent fathers and getting them to financially contribute - a notable early example is the 1576 Poor Law of England. In practice, paternity establishment has been revolutionized by late 20th-century developments in technologies that assist in identifying, or ruling out, a potential father, such as blood typing and genetic testing (US Department of Health and Human Services 2002). ${ }^{11}$

${ }^{9}$ Lerman and Sorensen (2003) provide a useful overview of child support enforcement. See also Committee on Ways and Means (2012), which has a concise legislative history of federal laws regarding child support.

${ }^{10}$ Federal laws began imposing minimum paternity establishment rates on states in 1988: initially set at $50 \%$, it has been incrementally increased to $90 \%$, as mandated by the 1996 welfare reform law. A provision of the Family Support Act of 1988 requires states to pay the up-front cost of genetic testing and to mandate a genetic test in a contested paternity case at the request of any party. Most states now have in-hospital Voluntary Acknowledgement of Paternity programs, which present acknowledgement forms to the man accompanying the mother in the hospital at the time of birth (Rossin-Slater 2017).

${ }^{11}$ For divorced couples-i.e., cases in which paternity is not legally in doubtchild support orders have been a component of alimony since before the 1975 
Once paternity is established, the next stage of the child support process is to obtain a child support order. The process for obtaining a child support order has been transformed and streamlined since 1975. If the mother is a recipient of public aid (IV-D cases), the IV-D agency will initiate child support proceedings against the person alleged to be the father, beginning with paternity establishment and through securing a child support order. A mother who is not a recipient of public aid has to bring a child support action to court herself, beginning with a paternity action and followed by a petition for child support. The child support order itself specifies the monthly child support amount, after consideration of the parents' income sources and the state guidelines for child support payments. The child support order will also specify the method of payment, which now may include wage garnishment or automatic withholding from public assistance, such as unemployment benefits, Social Security income, or tax returns.

\section{Model}

This section presents a simple model to explore both the mechanisms and the welfare consequences of a child support policy for the mother and father. ${ }^{12}$ Some predictions are straightforward; for instance, that women who would be single moms without child support are better off with a child support transfer. Other predictions are more subtle: for example, that women who would have a child and marry regardless of child support (and hence never use it) are better off, or that some men benefit from child support because it creates an ability for them to commit to future transfers, which they could not credibly do before. Unlike prior models of child support (Aizer and McLanahan 2006; Rossin-Slater 2017), the framework here endogenizes both marriage and fertility decisions, making it better suited to study the effect of child support on total nonmarital fertility separately from the fraction of births that occur outside marriage. The model also introduces abortion as a third alternative to marriage and single motherhood.

\section{A. Model Setup}

There exists a continuum of men and women who derive utility from one private composite good $c$, from sex, and from children. ${ }^{13}$ Individuals live for two periods and discount the future by a factor $\beta$.

Men and women are heterogeneous in their preference for children. Let $v_{F}$ denote a woman's individual-specific preference for children, assumed to be distributed over a support $[-V, V]$ with distribution $G_{F}$, and let $v_{M}$

federal law, although data on the frequency of payments or compliance with these orders prior to the creation of the OCSE are difficult to find.

${ }^{12}$ I leave aside the equally important consideration of the welfare of the child, which is beyond the scope of this paper but is discussed in Rossin-Slater (2017).

${ }^{13}$ For simplicity, we consider the choice between having one child and none, although the framework easily generalizes to the case of multiple children. 
denote a male's preference for children, distributed over the same support with distribution $G_{M}$. Taste parameters for children are assumed to be perfectly observable to both partners.

Information is perfect: all parameter realizations, including one's own value of children and one's partner's value of children, are perfectly known and are known at the start of the game.

In period 1 , all men and women are single and childless and are matched at random into couples. Men and women receive period 1 utility from sex only, which generates a fixed surplus $b>0$ for each partner. Period 1 utility is simply $U_{i}=b s_{i}$ for $i \in\{M, F\}$, where $s_{i}$ is an indicator for having premarital sex; individuals receive no wages and have no private consumption in period 1.

At the beginning of period 2, couples find out if there is a pregnancy, which occurs with exogenous probability $\lambda$ if the couple had premarital sex in period 1 . Women can abort the pregnancy at individual-specific cost $\delta$ distributed over support $\mathbb{R}^{+}$, which encapsulates any psychic, distance, or monetary costs and is perfectly observable to both partners.

Men and women receive period 2 utility from the private consumption good and from children. In this simple setup, women are assumed to be the default custodian of their children, and by assumption they derive equal utility from children whether or not they are married. Female utility in period 2 is written $U_{F}\left(c_{F}, k, a\right)=u\left(c_{F}\right)+v_{F} k(1-a)-\delta a$, where $c_{F}$ denotes consumption of the private good, normalized to have unit price; $k$ is a dummy variable indicating a pregnancy; $a$ is a variable indicating if the pregnancy is aborted; and $u(\cdot)$ is assumed to be strictly increasing and concave.

Men receive $v_{M}$ from children if they are married, which is diminished by a factor $\alpha$ if they are not married, where $0<\alpha<1$. This assumption reflects the lessened custodial rights of fathers outside marriage or a father's emotional distance from living away from his child (Chiappori and Oreffice 2008; Edlund 2013; Browning, Chiappori, and Weiss 2014). Period 2 male utility in marriage is $U_{M}\left(c_{M}, k, a\right)=u\left(c_{M}\right)+v_{M} k(1-a)$ and outside marriage is $U_{M}\left(c_{M}, k, a\right)=u\left(c_{M}\right)+\alpha v_{M} k(1-a)$. I emphasize that $c_{M}$ and $c_{F}$ are not constrained to be the same inside and outside marriage.

In period 2 , men earn wages $w_{b}$. Women earn $w_{b}$ too unless they have a child, in which case they earn $w_{\ell}<w_{b}$, reflecting both diminished earnings due to time away from work and the cost of raising the child (Bertrand, Goldin, and Katz 2010). Women who choose to abort the pregnancy keep their full wages in period 2.

\section{B. Timing of Marriage and Fertility Decisions}

In period 1, the couple decides on premarital sex. If both partners agree to premarital sex, then with probability $\lambda$ the female partner becomes pregnant at the beginning of period 2. (The game ends with outside options if the couple decides not to have sex.) 
In period 2, if there is no pregnancy there is no surplus of marriage, and the game ends with outside options. If there is a pregnancy, the couple decides on marriage; if both partners agree, they marry and bargain over marriage allocations; otherwise, they remain single. ${ }^{14}$ If the couple remains single, the female decides whether to abort the pregnancy. ${ }^{15}$ Note that bargaining over marriage allocations occurs at a time when the female partner considers abortion as one of her outside options.

Married couples bargain to a Pareto-efficient outcome: if both partners cannot be made better off under marriage, they do not marry. If both partners can be made better off under marriage, the couple marries and consumption is allocated to maximize weighted utility subject to both partners being better off, with a weight of 1 on the female partner and $\mu$ on men (Browning, Chiappori, and Weiss 2014).

The model is solved by backward induction in appendix A (apps. A-D are available online).

\section{Child Support}

The main focus here is the impact of a child support policy: a governmentenforced lump sum transfer $\tau>0$ from the father to the mother in the case of nonmarital fertility. ${ }^{16} \mathrm{I}$ impose one further assumption about the size of $\tau$ : that $\tau$ is small enough so that at least some men with distaste for childrenthat is, some men with $v_{M}<0$ - are still willing to have premarital sex.

The main implications of introducing a child support policy are summarized with the following proposition.

Proposition 1. If a child support policy is introduced, the following occur:

1. Strictly fewer women have an abortion, conditional on pregnancy.

2. Women who marry following a nonmarital pregnancy enjoy weakly more private consumption.

3. The effect on total pregnancies is ambiguous.

4. A set of couples unable to commit to marriage will have premarital sex.

\footnotetext{
${ }^{14}$ The timing of marriage and fertility decisions in the model is such that all marriages are "shotgun marriages" in the sense that they are triggered by the pregnancy and would not occur otherwise. One could include an additional match-specific nonmonetary benefit of marriage $\theta$, as in Chiappori and Weiss (2006), which would introduce both shotgun and nonshotgun marriages.

${ }^{15}$ Because children are the only surplus of marriage and preferences for children are public, no abortions will occur in marriage.

${ }^{16}$ An important feature of child support is to provide additional custodial rights to the father, which would be represented here by an increase in $\alpha$ for nonmarried fathers; I consider this case in app. A.
} 
Proof. See appendix A.

The intuition behind proposition 1 is as follows. Under a child support policy, strictly fewer women abort a pregnancy because being a single mom is more attractive with added financial support from the father. Married women have greater bargaining power in their marriage because their outside option - being a single mom - is now more attractive, raising the private consumption required for them to marry. The total effect on pregnancies is ambiguous because while women's willingness to become pregnant increases, men who dislike children are less willing to have premarital sex. However, a set of couples who previously faced a commitment problem will now have premarital sex and will not marry. Prior to child support, a set of men were willing to commit ex ante to future transfers to have premarital sex, but this commitment was not credible; ex post these men would walk away. The commitment problem is solved by child support, which enforces commitment from men in couples who will not marry.

\section{Welfare}

All women are at least weakly better off by the introduction of child support. Women who marry have weakly higher bargaining power within marriage. Marginal women who prior to child support would have sex only with commitment and now will have sex without commitment to marry are better off too, because they receive higher consumption in marriage and receive the utility benefit of sex. Inframarginal women who, prior to child support, would have sex without commitment are strictly better off too because they now receive child support payments in the event of a nonmarital pregnancy. Women who continue to reject premarital sex are no worse off than they were prior to the reform.

Let us now consider men. Men who can credibly commit to marriage $\left(v_{M}>0\right)$-are weakly worse off because they have weakly lower bargaining power in marriage. Some men are weakly better off: those for whom child support solves the limited commitment problem. These men are better off because without child support they were willing to commit ex ante, but ex post they would walk away; child support enforces commitment from these men.

It is important to emphasize that in this model child support is welfare enhancing for the marginal women who no longer marry. This is in contrast to the shotgun marriage model of Akerlof, Yellen, and Katz (1996), in which a decline in shotgun marriages is welfare diminishing for these marginal women. ${ }^{17}$

${ }^{17}$ The decline in shotgun marriages in the Akerlof, Yellen, and Katz (1996) model arises as a result of a new technology - contraceptives and abortion-which is adopted by an exogenous fraction of women. The adoption of this technology by a large 


\section{Data Sources}

This section describes the data sources and presents descriptive statistics.

\section{A. Child Support Legislative Data}

This study uses a state-year database of child support legal enactments, used in prior work by Case (1998) and Plotnick et al. (2007) and which includes laws at each stage of the child support process.

These data are available for the years 1977-92 and for all US states with the exception of Hawaii and Alaska. I construct a state-year legislative index, denoted $C S_{s t}$, which is an average of nine indicator variables, each of which represents a different child support law and takes the value of 1 if the associated law is in effect in state-year st. Hence, the index is a continuous variable ranging from 0 to 1 , where 0 reflects that the state has none of the nine laws in effect and 1 reflects that the state has all nine laws in effect. A singledimensional index increases power in the analysis and allows us to draw inferences about the aggregate impact of the rollout, but it has the disadvantage of imposing linearity so that each law is assumed to have the same marginal effect, abstracting away from any heterogeneity in their impact. I explore heterogeneity in the main results in appendix B.

The nine laws included in the analysis are (1) a law requiring immediate income withholding for new or modified child support cases, deducting child support obligations from the obligor's paycheck; (2) a law allowing the custodial parent to place a lien on the noncustodial parent's property; (3) a law permitting genetic tests to be used to resolve disputed cases; (4) a law allowing paternity to be established while the child is below 18 years of age; (5) a law requiring the provision of local child support collection and enforcement services to nonrecipients of Aid to Families with Dependent Children (AFDC); (6) a law requiring withholding of arrearages from parents who are delinquent on their payment; (7) a law creating criminal penalties for failure to pay child support; (8) a law establishing the right to bring a child support action against a parent residing in another state; and (9) a law creating a central registry for child support payments.

Figure 1 plots the mean adoption rate across states for each of the nine different child support statutes used in the analysis. The figure shows a dramatic increase in adoption of statutes and considerable variation in the timing

enough fraction of women induces the shotgun marriage equilibrium to switch to a second equilibrium in which men no longer have to promise to marry as a means for obtaining premarital sex. The exogenous fraction of women who fail to adopt the new technology are worse off because they can no longer extract a shotgun marriage promise and no longer marry. In the model presented here, by contrast, the marginal women are better off because they get additional transfers by not marrying their male partners. 


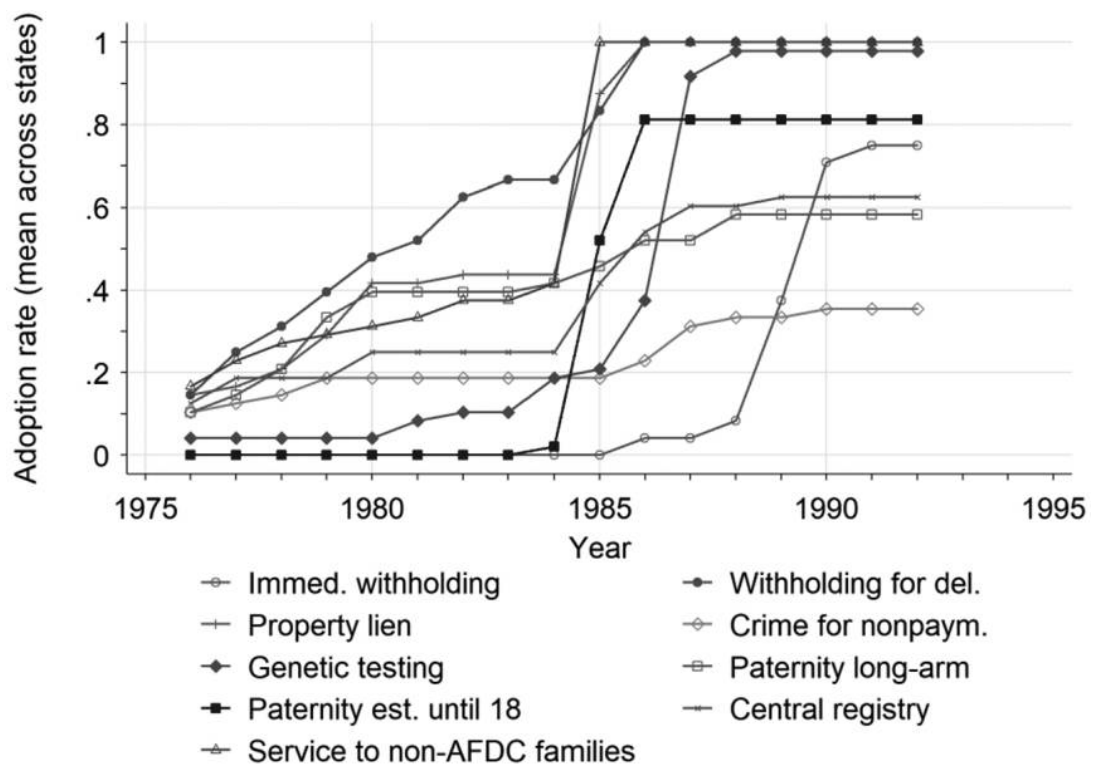

FIG. 1.-Child support statute adoption. This figure plots the mean rate of adoption across states for each of the nine types of child support statutes used in the analysis. AFDC $=$ Aid to Families with Dependent Children. A color version of this figure is available online.

and abruptness of enactments across states. While incremental changes to child support collection and enforcement have taken place since the 1970s, with the gradual trend being toward greater enforcement and stronger measures to promote collection, certain federal laws brought abrupt changes, which can account for the dramatic rise in certain types of laws. For example, in 1984 Congress enacted Public Law 98-378, which required states to implement income withholding procedures for parents delinquent on payments, and hence in figure 1 we see a big jump in state laws withholding for delinquency between 1984 and 1986. Similarly, Public Law 100-485 was enacted in October of 1988 and implemented income withholding procedures that would take effect immediately, unless the parties were able to come to an alternate arrangement; figure 1 shows a spike in state laws introducing immediate withholding between 1988 and $1990 .^{18}$

${ }^{18}$ Accompanying the strengthening of policies, child support enforcement expenditures per single mother roughly tripled between 1980 and 2000, from $\$ 200$ per single-mother family to approximately $\$ 600$, in constant 2000 USD (Freeman and Waldfogel 2001). 


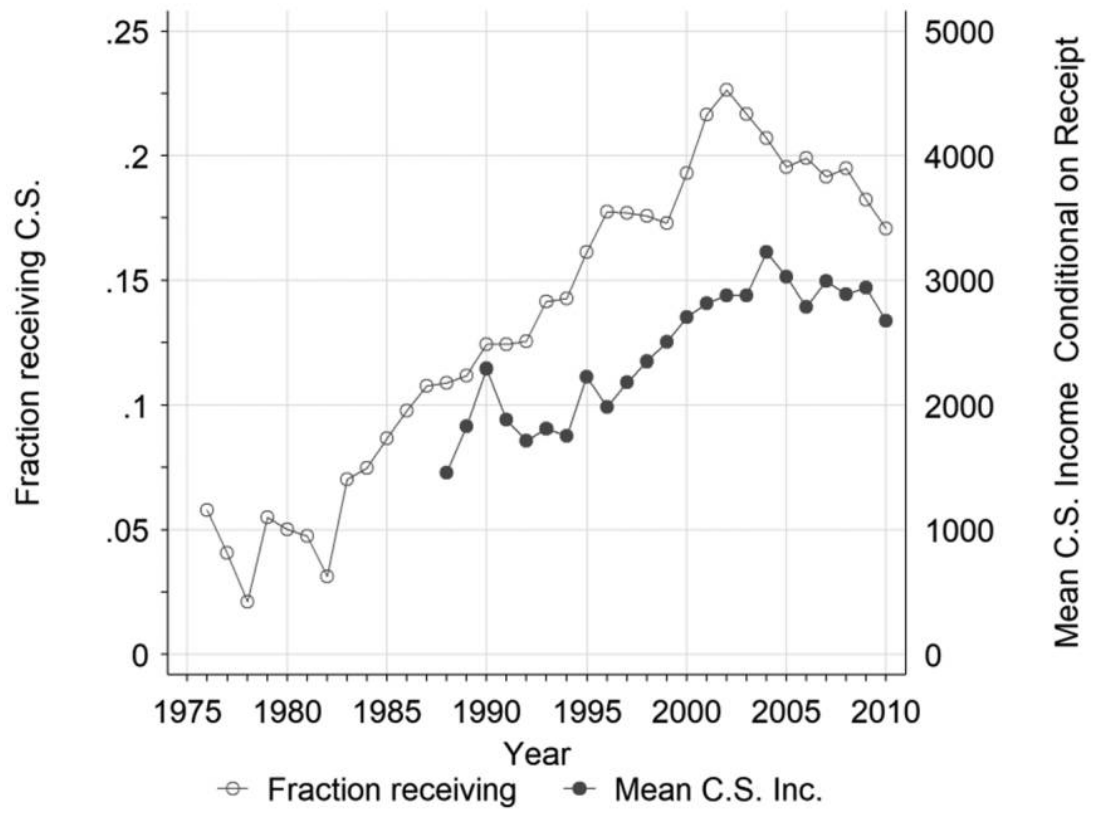

FIG. 2.-Child support income receipt. This figure plots two annual series: (1) the fraction of never-married mothers with an absent father receiving any child support income and (2) mean child support income received (in 2000 USD) for those receiving any child support. Source: March Current Population Survey. A color version of this figure is available online.

\section{B. Child Support Income Data}

Child support income data come from the Integrated Public Use Microdata Series March Current Population Survey (CPS; Flood et al. 2017). ${ }^{19}$ Figure 2 shows that child support income increased substantially over this period. ${ }^{20}$ The series plotted on the left $Y$-axis shows the fraction of

19 The March CPS has an advantage over alternative data sources recording information about child support in that it offers the longest time series, allowing one to observe whether a mother received any child support going back to 1977. By contrast, the April CPS Child Support Supplement was introduced in 1979 and has been repeated every other year since 1982. SIPP, which also records information about child support receipt, has its earliest sample in 1984. The March CPS has the disadvantage of not containing information on child support awards or amount owed by the nonresident parent.

${ }^{20}$ For years 1977-87 I use the GOTALCH variable, which is an indicator for the respondent having received alimony or child support income over the past year. I use the sample of never-married women only; hence, a positive response indicates child support income, not alimony. The March CPS began collecting data on child support as a separate income category in 1988, and I use this CSINCOME variable for 1988 and later years. 
never-married mothers with a custodial child under 18 and an absent father who report receiving any child support income for years 1976-2010. The series plotted on the right $Y$-axis shows the average annual pretax child support income (in 2000 USD) for those reporting any child support income. The second series shows that the dollar amount received per mother has been steadily increasing over the sample period, and the amount represents between $10 \%$ and $15 \%$ of total household income for mothers in the sample. (I omit the period 1977-87 from this second series because it is not possible to separate child support income from other residual income categories in this period.)

Note that in spite of the dramatic increase in the fraction of never-married mothers receiving child support from 1980 to 2000, the fraction never surpasses $25 \%$. This may reflect underreporting of income, which has been documented in the March CPS for child support and other transfer programs and appears to be more pronounced among lower-income respondents (Wheaton 1997; Meyer, Mok, and Sullivan 2015; Meyer and Mittag 2019). ${ }^{21}$

\section{Marriage and Fertility Data}

The marriage and fertility data used in the main analysis come from the restricted Survey of Income and Program Participation (SIPP), which is available in the Census Bureau's Research Data Center. I use years 1992, 1993, and 1996, which have retrospective marital and fertility histories in Topic Module 2 as well as state identifiers and individual demographic controls. The state of residence identifier in SIPP allows me to link these data to the state-level child support legislative data. ${ }^{22}$

I emphasize that the restricted SIPP does not include data on miscarriages or abortions; hence, the analysis of marriage following a first pregnancy is, more precisely, an analysis of marriage following a pregnancy that results in the first live birth reported by the respondent. ${ }^{23}$

Table 1 displays sample means and standard deviations for the SIPP sample. The sample includes women aged 18-44 in each time period given in the column heading. I define a shotgun marriage as a first marriage occurring

${ }^{21}$ In terms of dollar amounts, according to the OCSE's 2000 annual report, the amount of current support due in fiscal year 2000 was $\$ 23.03$ billion, while the amount of current support distributed was $\$ 12.9$ billion, or $56 \%$ of the total.

${ }^{22}$ Note that all reported numbers of observations and degrees of freedom in $F$-statistics that come from the restricted SIPP data are rounded according to census disclosure requirements.

${ }^{23}$ For conciseness, throughout the empirical analysis using SIPP data, I use the term "pregnancies" to refer to pregnancies that result in a birth. Section V.C considers the direct effect of child support on abortions using aggregated data at the state-year level. Section V.D considers the potential for selection bias in the marriage analysis that may occur due to missing data on miscarriages and abortion. 
Table 1

Descriptive Statistics of the Sample

\begin{tabular}{lccccc}
\hline & All Years & $1977-80$ & $1981-84$ & $1985-88$ & $1989-92$ \\
\hline Person characteristics: & & & & & \\
Shotgun marriage rate & .36 & .38 & .39 & .36 & .33 \\
& $(.48)$ & $(.48)$ & $(.49)$ & $(.48)$ & $(.47)$ \\
Fraction of marriages: shotgun & .10 & .09 & .11 & .10 & .11 \\
& $(.30)$ & $(.29)$ & $(.31)$ & $(.30)$ & $(.32)$ \\
Fraction of pregnancies: nonmarital & .31 & .26 & .29 & .32 & .35 \\
& $(.46)$ & $(.44)$ & $(.45)$ & $(.47)$ & $(.48)$ \\
Fraction of births: nonmarital & .21 & .18 & .19 & .22 & .25 \\
& $(.41)$ & $(.38)$ & $(.39)$ & $(.41)$ & $(.43)$ \\
Child support: & & & & & \\
Child support index & .46 & .19 & .27 & .64 & .78 \\
& $(.29)$ & $(.13)$ & $(.13)$ & $(.15)$ & $(.12)$ \\
Child support expenditures & 223.62 & 179.07 & 179.65 & 218.94 & 287.87 \\
& $(111.82)$ & $(95.53)$ & $(92.22)$ & $(102.67)$ & $(113.00)$ \\
State-level controls: & & & & & \\
Percent black & .12 & .12 & .12 & .12 & .13 \\
& $(.08)$ & $(.07)$ & $(.07)$ & $(.08)$ & $(.08)$ \\
Male unemployment rate & .08 & .07 & .10 & .07 & .07 \\
& $(.03)$ & $(.02)$ & $(.03)$ & $(.02)$ & $(.02)$ \\
Females with college degrees & .44 & .42 & .43 & .44 & .46 \\
& $(.03)$ & $(.02)$ & $(.03)$ & $(.02)$ & $(.02)$ \\
Female labor force participation & .64 & .59 & .63 & .66 & .69 \\
& $(.06)$ & $(.04)$ & $(.04)$ & $(.04)$ & $(.04)$ \\
Urban & .72 & .69 & .70 & .74 & .75 \\
& $(.22)$ & $(.23)$ & $(.23)$ & $(.22)$ & $(.21)$ \\
Welfare & .03 & .03 & .03 & .03 & .03 \\
& $(.01)$ & $(.01)$ & $(.01)$ & $(.01)$ & $(.01)$ \\
Single-mom welfare & .10 & .10 & .10 & .10 & .09 \\
& $(.03)$ & $(.03)$ & $(.03)$ & $(.03)$ & $(.03)$ \\
Poverty & .13 & .12 & .14 & .14 & .13 \\
& $(.04)$ & $(.03)$ & $(.04)$ & $(.03)$ & $(.03)$ \\
\hline Nore & & & & & \\
& & & & &
\end{tabular}

NoTE.-This table reports means and standard deviations (in parentheses) of the marriage data from the restricted Survey of Income and Program Participation, the child support legislative data, and the state-year controls. The shotgun marriage rate is defined as the fraction of nonmarital pregnancies (resulting in births) that are resolved in a marriage between 0 and 8 months prior to birth. Nonmarital pregnancy refers to the fraction of women with a nonmarital conception resulting in birth.

between 0 and 8 months prior to the first birth, following Akerlof, Yellen, and Katz (1996). Figure 3 shows a 3-year moving average of the shotgun marriage rate: the fraction of year $t$ nonmarital (first) pregnancies resolved in a marriage 0-8 months prior to birth. ${ }^{24}$ The shotgun marriage rate is more than $50 \%$ in 1970 and declines to slightly more than $20 \%$ in $1996 .{ }^{25}$ It is

${ }^{24}$ Because only live births are observed, the shotgun marriage rate is computed as the fraction of women who are never married as of 9 months prior to their first birth who become married between 0 and 8 months prior to the birth.

${ }^{25}$ The decline in shotgun marriages presented here is consistent with Akerlof, Yellen, and Katz (1996) and complements the empirical finding in the sociology 


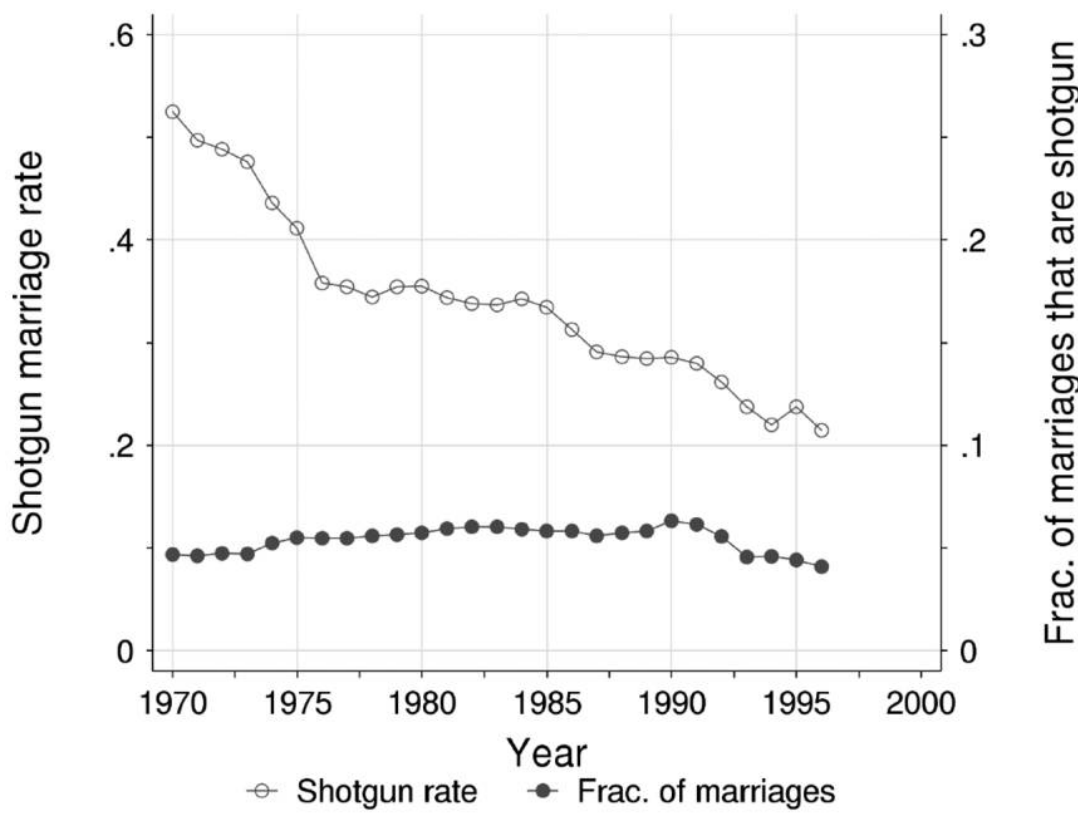

FIG. 3.- Shotgun marriage rates by year. The figure uses data from the restricted Survey of Income and Program Participation and plots 3-year moving averages of the following two series: (1) the fraction of first births that are resolved in a marriage 0-8 months before birth, plotted on the left $Y$-axis, and (2) the fraction of first marriages that are shotgun marriages, plotted on the right $Y$-axis. A color version of this figure is available online.

important to stress that the decline in shotgun marriages preceded the strengthening of child support laws by about 5 years; hence, the decline cannot be explained completely by the advent of child support laws. ${ }^{26}$ Figure 3 also plots the fraction of total first marriages in year $t$ that are shotgun marriages, showing a broadly stable fraction until the early 1990s and then declining. ${ }^{27}$

literature that since the 1970s, pregnancies outside marriage are far more likely to be resolved in cohabitation rather than marriage (Lichter, Sassler, and Turner 2014).

${ }^{26}$ Child support was introduced in part as a response to the increase in the number of single-mother families on welfare. While child support may have succeeded in reducing welfare receipt among single moms (Huang, Garfinkel, and Waldfogel 2004), this paper argues that it may have had the unintended consequence of actually increasing the fraction of single-mother families, through its effect on the marriage decision.

${ }^{27}$ Appendix D presents additional descriptive analysis of shotgun marriages, based on the National Survey of Families and Households and SIPP, showing that they differ qualitatively from nonshotgun marriages in terms of marital happiness and divorce hazard rates. People in shotgun marriages are less likely to report being 


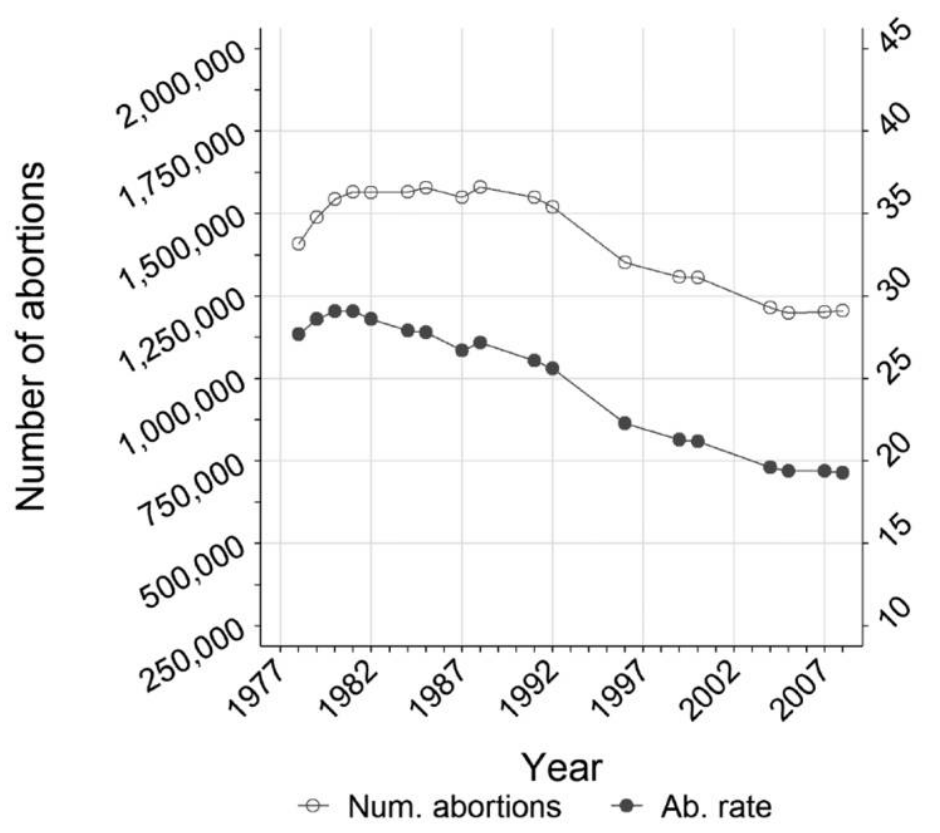

FIG. 4.- Trends in abortions in the United States. A color version of this figure is available online.

\section{Abortion Data}

State-year data on abortion totals and the number of abortion providers come from the Guttmacher Institute and are based on periodic surveys of abortion providers (Henshaw and Kost 2008). The data report total abortions and abortions per 1,000 women aged $15-44$, both by state of residence and by state of occurrence, and are available for years 1978-2008, with gaps in years 1983,1986, 1989, and 1990 in the analysis period. I use abortions by state of residence rather than state of occurrence since child support laws will affect women by their state of residence. The data also include counts of the number of abortion providers in each state and year; these include hospitals, clinics, or physicians' offices where abortions are performed. I use these counts to construct a proxy for abortion availability: the number of abortion providers per 100,000 women aged 15-44.

Figure 4 depicts trends in total abortions and in the abortion rate, which is defined as the number of abortions per 1,000 women aged 15-44. The decline in the abortion rate over 1978-92 continues until about 2004, although the child support legislative database does not cover such recent years.

happy in their marriage, are more likely to report having discussed separation with their spouse, and are more likely to divorce. 
Table 2

Descriptive Statistics: Guttmacher, General Social Survey (GSS), and State Legislature Data

\begin{tabular}{|c|c|c|c|c|c|}
\hline & $\begin{array}{l}\text { All } \\
\text { Years }\end{array}$ & $1977-80$ & $1981-84$ & $1985-88$ & 1989-92 \\
\hline \multicolumn{6}{|l|}{ Abortion statistics: } \\
\hline Number of abortions per 1,000 women & $\begin{array}{c}27.68 \\
(10.57)\end{array}$ & $\begin{array}{l}28.65 \\
(9.82)\end{array}$ & $\begin{array}{l}28.56 \\
(10.55)\end{array}$ & $\begin{array}{l}27.24 \\
(11.08)\end{array}$ & $\begin{array}{c}25.86 \\
(10.67)\end{array}$ \\
\hline $\begin{array}{l}\text { Number of abortion providers } \\
\text { (per 100,000 women) }\end{array}$ & $\begin{array}{l}4.82 \\
(2.90)\end{array}$ & $\begin{array}{c}5.31 \\
(3.01)\end{array}$ & $\begin{array}{c}5.18 \\
(2.98)\end{array}$ & $\begin{array}{l}4.56 \\
(2.82)\end{array}$ & $\begin{array}{l}4.06 \\
(2.54)\end{array}$ \\
\hline \multicolumn{6}{|l|}{ Societal attitudes: } \\
\hline Abortion legal for any reason & $\begin{array}{l}.43 \\
(.11)\end{array}$ & $\begin{array}{l}.40 \\
(.12)\end{array}$ & $\begin{array}{l}.42 \\
(.12)\end{array}$ & $\begin{array}{l}.41 \\
(.10)\end{array}$ & $\begin{array}{l}.47 \\
(.11)\end{array}$ \\
\hline Abortion legal if not married & $\begin{array}{l}.46 \\
(.11)\end{array}$ & $\begin{array}{l}.47 \\
(.11)\end{array}$ & $\begin{array}{l}.47 \\
(.11)\end{array}$ & $\begin{array}{l}.43 \\
(.09)\end{array}$ & $\begin{array}{l}.49 \\
(.11)\end{array}$ \\
\hline Abortion legal if married & $\begin{array}{c}.46 \\
(.11)\end{array}$ & $\begin{array}{l}.47 \\
(.11)\end{array}$ & $\begin{array}{l}.48 \\
(.12)\end{array}$ & $\begin{array}{l}.44 \\
(.10)\end{array}$ & $\begin{array}{l}.48 \\
(.12)\end{array}$ \\
\hline Abortion legal if woman's health endangered & $\begin{array}{l}.90 \\
(.04)\end{array}$ & $\begin{array}{l}.91 \\
(.03)\end{array}$ & $\begin{array}{l}.90 \\
(.04)\end{array}$ & $\begin{array}{l}.89 \\
(.04)\end{array}$ & $\begin{array}{l}.92 \\
(.04)\end{array}$ \\
\hline Abortion legal if pregnant as a result of rape & $\begin{array}{l}.82 \\
(.06)\end{array}$ & $\begin{array}{c}.81 \\
(.06)\end{array}$ & $\begin{array}{l}.82 \\
(.06)\end{array}$ & $\begin{array}{l}.80 \\
(.06)\end{array}$ & $\begin{array}{l}.85 \\
(.06)\end{array}$ \\
\hline Abortion legal if strong chance of birth defect & $\begin{array}{l}.81 \\
(.07)\end{array}$ & $\begin{array}{l}.83 \\
(.05)\end{array}$ & $\begin{array}{l}.81 \\
(.05)\end{array}$ & $\begin{array}{l}.79 \\
(.07)\end{array}$ & $\begin{array}{l}.82 \\
(.09)\end{array}$ \\
\hline Abortion legal if low income & $\begin{array}{l}.49 \\
(.10)\end{array}$ & $\begin{array}{l}.52 \\
(.09)\end{array}$ & $\begin{array}{l}.50 \\
(.10)\end{array}$ & $\begin{array}{l}.45 \\
(.09)\end{array}$ & $\begin{array}{l}.52 \\
(.11)\end{array}$ \\
\hline Premarital sex OK & $\begin{array}{l}.50 \\
(.10)\end{array}$ & $\begin{array}{l}.48 \\
(.08)\end{array}$ & $\begin{array}{l}.49 \\
(.10)\end{array}$ & $\begin{array}{l}.52 \\
(.11)\end{array}$ & $\begin{array}{l}.49 \\
(.11)\end{array}$ \\
\hline Should divorce be easier to obtain & $\begin{array}{l}.31 \\
(.09)\end{array}$ & $\begin{array}{l}.35 \\
(.09)\end{array}$ & $\begin{array}{l}.27 \\
(.08)\end{array}$ & $\begin{array}{l}.30 \\
(.08)\end{array}$ & $\begin{array}{l}.32 \\
(.10)\end{array}$ \\
\hline Sex education in public schools & $\begin{array}{l}.90 \\
(.05)\end{array}$ & $\begin{array}{l}.85 \\
(.06)\end{array}$ & $\begin{array}{l}.90 \\
(.05)\end{array}$ & $\begin{array}{l}.91 \\
(.04)\end{array}$ & $\begin{array}{l}.92 \\
(.04)\end{array}$ \\
\hline US spends too much on welfare & $\begin{array}{l}.45 \\
(.12)\end{array}$ & $\begin{array}{l}.58 \\
(.08)\end{array}$ & $\begin{array}{l}.46 \\
(.07)\end{array}$ & $\begin{array}{l}.42 \\
(.10)\end{array}$ & $\begin{array}{l}.37 \\
(.11)\end{array}$ \\
\hline \multicolumn{6}{|l|}{$\begin{array}{l}\text { State legislature composition } \\
\text { (house-senate-governor): }\end{array}$} \\
\hline D-D-D & $\begin{array}{l}.38 \\
(.49)\end{array}$ & $\begin{array}{l}.53 \\
(.50)\end{array}$ & $\begin{array}{l}.38 \\
(.49)\end{array}$ & $\begin{array}{l}.36 \\
(.48)\end{array}$ & $\begin{array}{l}.27 \\
(.44)\end{array}$ \\
\hline D-D-R & $\begin{array}{l}.32 \\
(.47)\end{array}$ & $\begin{array}{l}.22 \\
(.41)\end{array}$ & $\begin{array}{l}.34 \\
(.47)\end{array}$ & $\begin{array}{l}.30 \\
(.46)\end{array}$ & $\begin{array}{l}.40 \\
(.49)\end{array}$ \\
\hline D-R-D & $\begin{array}{l}.14 \\
(.35)\end{array}$ & $\begin{array}{l}.08 \\
(.28)\end{array}$ & $\begin{array}{l}.10 \\
(.30)\end{array}$ & $\begin{array}{l}.18 \\
(.38)\end{array}$ & $\begin{array}{l}.21 \\
(.40)\end{array}$ \\
\hline $\mathrm{D}-\mathrm{R}-\mathrm{R}$ & $\begin{array}{l}.04 \\
(.19)\end{array}$ & $\begin{array}{l}.01 \\
(.12)\end{array}$ & $\begin{array}{l}.05 \\
(.22)\end{array}$ & $\begin{array}{l}.04 \\
(.20)\end{array}$ & $\begin{array}{l}.04 \\
(.20)\end{array}$ \\
\hline $\mathrm{R}-\mathrm{R}-\mathrm{R}$ & $\begin{array}{l}.04 \\
(.19)\end{array}$ & $\begin{array}{l}.05 \\
(.22)\end{array}$ & $\begin{array}{l}.05 \\
(.21)\end{array}$ & $\begin{array}{l}.03 \\
(.18)\end{array}$ & $\begin{array}{c}.02 \\
(.15)\end{array}$ \\
\hline R-R-D & $\begin{array}{c}.05 \\
(.21)\end{array}$ & $\begin{array}{c}.05 \\
(.21)\end{array}$ & $\begin{array}{c}.06 \\
(.24)\end{array}$ & $\begin{array}{l}.05 \\
(.21)\end{array}$ & $\begin{array}{c}.03 \\
(.17)\end{array}$ \\
\hline R-D-R & $\begin{array}{c}.02 \\
(.14)\end{array}$ & $\begin{array}{c}.02 \\
(.15)\end{array}$ & $\begin{array}{c}.02 \\
(.15)\end{array}$ & $\begin{array}{c}.03 \\
(.16)\end{array}$ & $\begin{array}{c}.01 \\
(.09)\end{array}$ \\
\hline
\end{tabular}


Table 2 (Continued)

\begin{tabular}{lcccccc}
\hline & All & & & & \\
& Years & $1977-80$ & $1981-84$ & $1985-88$ & $1989-92$ \\
\hline R-D-D & .02 & .03 & .01 & .01 & .02 \\
\multirow{3}{*}{ Other } & $(.13)$ & $(.17)$ & $(.08)$ & $(.10)$ & $(.14)$ \\
& .00 & .01 & .00 & .00 & .00 \\
& $(.05)$ & $(.09)$ & $(.00)$ & $(.00)$ & $(.06)$ \\
\hline
\end{tabular}

NoтE.- This table reports means and standard deviations (in parentheses) of the Guttmacher data on abortions per 1,000 women aged 15-44 and the number of abortion providers per 100,000 women. Societal attitude data are from the GSS, for respondents aged 18-44. State legislature composition data comes from Halvorsen and Jakobsen (2013). See app. B for GSS variable definitions.

Table 2 presents descriptive statistics of the abortion data over the sample period used in the analysis. Total abortions declined from 28.7 per 1,000 women per year in the $1978-80$ period to 25.9 in the $1990-92$ period. This downward trend has been accompanied by a downward trend in the number of abortion providers per 100,000 women aged 15-44, from 5.3 in the $1977-80$ period to 4.1 in the $1990-92$ period.

\section{E. State-Year Controls, Societal Attitudes, and Political Affiliation Data}

The state-level demographic controls come from the March CPS. Table 1 presents summary statistics of the mean and standard deviations of statelevel controls used in the main analysis, including percent black, male unemployment rate, share of college degree holders who are female, the female labor force participation rate, share of the state population living in an urban area, share of state residents collecting welfare, share of single moms on welfare, and the poverty rate.

Survey data on attitudes toward abortion, sex, marriage, welfare, and women come from the General Social Survey (GSS). I include variables from the GSS as controls in the analysis to lend further support that trends in attitudes are not behind the main results on marriage and abortion. See table B.1 (tables B.1-B.8, C.1-C.4, D.1-D.3 are available online) for further details on the survey questions used with their full text and the years available. I restrict the data to survey respondents aged $18-44$, since this is the age group considered in the fertility and marriage analysis; I aggregate survey responses to the region-year level. ${ }^{28}$

I use data on the majority party of state legislatures and the party affiliation of governors that were assembled by Halvorsen and Jakobsen (2013). The data on state legislatures come from the National Conference of State Legislatures, while the data on state governors are from the National Governors Association. Table 2 summarizes the eight possible combinations of

${ }^{28}$ State identifiers are not available in the public-use GSS data. Even with access to state identifiers, however, sample sizes become too small: there are approximately 1,700 total responses per year over the 1977-92 period. 
party leadership (Democratic or Republican) of the state house, state senate, and the governor's office. ${ }^{29}$

\section{Empirical Strategy}

This section first explores determinants of state-level adoption of child support statutes, presenting evidence that state-level characteristics are not predictive of the timing and geography of statute adoption. I present evidence that these laws indeed have had an effect on the likelihood of receiving child support income. I then consider the effect of child support laws on statelevel abortion rates. Last, I present the main estimating equation for child support's effect on marriage, discuss the assumptions required for identification, and present the results.

\section{A. The Child Support Rollout}

The empirical strategy of this paper is motivated by the idea that the exact timing of pregnancy relative to the legislative regime is difficult for the individual to control. Identification in this setting nevertheless faces the challenge that state-level trends in supply and demand factors for marriage may be correlated with the timing of states' adoption of child support statutes, which I explore now.

As a preliminary step, I regress the child support enforcement index defined above on state fixed effects, time fixed effects, and time-varying controls that are likely to covary with marital attitudes or marital opportunities. These regressions are reported in table 3 . I find that $91.7 \%$ of the variation in the child support index can be attributed to time-invariant state effects and common time effects (col. 1), while $0.03 \%$ of the variation in the child support index can be attributed to time-varying factors (col. 2): welfare recipiency rate, male unemployment rate, single mom share on welfare, female participation rate, female college share, percent black, urban share, poverty rate, and college/high school premium. In column 2, an $F$-test of the null hypothesis that these time-varying controls are jointly equal to zero rejects the null at the $10 \%$ significance level $(F(7,697)=1.92$ with $p=.064)$, which motivates the inclusion of these controls in the main analysis. I emphasize that the main results change minimally with the inclusion of these controls. Column 3 presents the long change of the state-level child support index over the entire sample period regressed on baseline covariates. A joint test of the null that the covariates are jointly equal to zero fails to reject $(F(7,39)=$ 1.05 with $p=.412$ ). Nevertheless, the potential for state trends over this period motivates the inclusion of state-level (or region-level) time trends as a robustness check later in the analysis.

${ }^{29}$ The "other" category refers to states with independent governors. Nebraska has a unicameral legislature, and its data are coded as having the same party affiliation for both the house and the senate. 
Table 3

State-Year Characteristics and the Child Support Rollout

\begin{tabular}{lccc}
\hline & $(1)$ & $(2)$ & $(3)$ \\
\hline Percent black & & .020 & .028 \\
& & $(.021)$ & $(.032)$ \\
Male unemployment rate & $.010 * *$ & $-.074 *$ \\
& & $(.005)$ & $(.039)$ \\
Female college share & -.004 & $-.053^{*}$ \\
Female participation rate & $(.004)$ & $(.028)$ \\
& .001 & -.049 \\
Welfare recipient & $(.010)$ & $(.038)$ \\
& $.019 * *$ & .020 \\
Welfare recipient (single mom) & $(.007)$ & $(.042)$ \\
& & -.002 & -.008 \\
Poverty rate & $(.006)$ & $(.037)$ \\
& & .006 & -.016 \\
College premium & $(.010)$ & $(.035)$ \\
& & -.003 & -.021 \\
State fixed effects & $(.004)$ & $(.025)$ \\
Year fixed effects & & Yes & \\
Observations & & Yes & \\
$R^{2}$ & & 768 & 48 \\
\hline
\end{tabular}

NoTE.-This table presents regressions of the child support policy index on state and year fixed effects, along with time-varying controls that are likely to covary with marital attitudes or marital opportunities. In cols. 1 and 2 the dependent variable is $C S_{s,}$ and in col. 3 the dependent variable is $C S_{s, 1992}-C S_{s, 1977}$. Controls are described in the text and are standardized to have mean 0 and standard deviation 1 across state-year cells.

$* p<.10$.

$* * p<.05$.

Next, I consider whether baseline state characteristics predict future innovations in child support laws. The idea here is that state-level variables, including both outcomes of interest and controls, are correlated with supply and demand factors for marriage. If they predict future innovations in the law, it would suggest either (1) a reverse causality story, in which changes in fertility drive child support law adoption, or (2) a violation of the common trends assumption, because baseline state characteristics are predictive of the future path of their adoption of laws.

I estimate the following regression:

$$
\Delta C S_{s t}=\alpha+\psi_{t}^{\prime} w_{s, 1977}+\eta_{s}+\xi_{t}+\epsilon_{s t},
$$

where $\Delta C S_{s t}=C S_{s t}-C S_{s, t-1}$ and $w_{s, 1977}$ is a vector of baseline state-level outcome variables and controls, normalized to have mean 0 and standard deviation 1 in the baseline year. The vector $w_{s, 1977}$ includes the following: the shotgun marriage rate, the abortion rate, the 10-year divorce hazard, the black incarceration rate, the fraction black in the population, the male unemployment rate, the share of college graduates who are female, the female participation rate, the share of urban residents, the fraction of the 
population receiving welfare, the fraction of single moms on welfare, the poverty rate, and the college/high school premium. The baseline year is 1977 for all variables in $w_{s, 1977}$ except, because of data limitations, for the black incarceration rate, which has the baseline year 1980, and the abortion rate, which has the baseline year 1978. The regression includes state fixed effects and year fixed effects $\left(\eta_{s}\right.$ and $\xi_{t}$, respectively).

The estimates $\hat{\psi}_{t}$ can be interpreted as the effect of increasing by 1 standard deviation a state's baseline level of a particular characteristic on a future increase in the child support law index, net of the average state and time effects. Figure 5 plots the estimated coefficients $\hat{\psi}_{t}$ and their associated $95 \%$ confidence intervals. The first row of figure 5 shows that baseline levels of the main outcome variables studied in this paper - the shotgun marriage rate and the abortion rate- do not predict future innovations in child support laws and do not appear to be driving changes in child support statute adoption.

The second and third rows of figure 5 show that baseline state-level controls do not appear to predict future innovations nor time trends in the child support law index. Female marital opportunities, which may be related to the female labor force participation rate, the female share of college degree holders, or the fraction of black men incarcerated, do not appear to predict future changes in child support statute adoption. ${ }^{30}$ Taken as a whole, the panels of figure 5 suggest that the timing of the rollout has no clear systematic relationship with baseline state-level marital patterns or demographics. Appendix $C$ explores this question further using the social attitudes data from the GSS, finding that social attitudes do not correlate strongly with law adoption once we remove region and year fixed effects.

\section{B. The Effect of Child Support Laws on Income}

This section aims to show that child support laws at the time of pregnancy indeed have an effect on future child support income for single moms.

I restrict the analysis to the population of never-married mothers who report having a custodial child in the household under 18 years of age and who also report the father living outside the household. I then estimate the following regression:

$$
\operatorname{Inc}_{i s t}=\beta_{0}+\beta_{1} C S_{s, t-a-1}+\gamma^{\prime} x_{i s t}+\alpha^{\prime} w_{s t}+\epsilon_{i s t},
$$

${ }^{30}$ Certain variables, such as the share receiving welfare, the poverty rate, and the share of single moms receiving welfare, are borderline statistically significant in years 1986-87. To formally test significance, I perform an $F$-test of each variable's year coefficients being jointly equal to zero and report the results in table B.2. In none of the cases do we reject the $F$-test of equality at the $10 \%$ significance level. I also fail to reject an $F$-test of all variables' year coefficients being jointly equal to zero. 

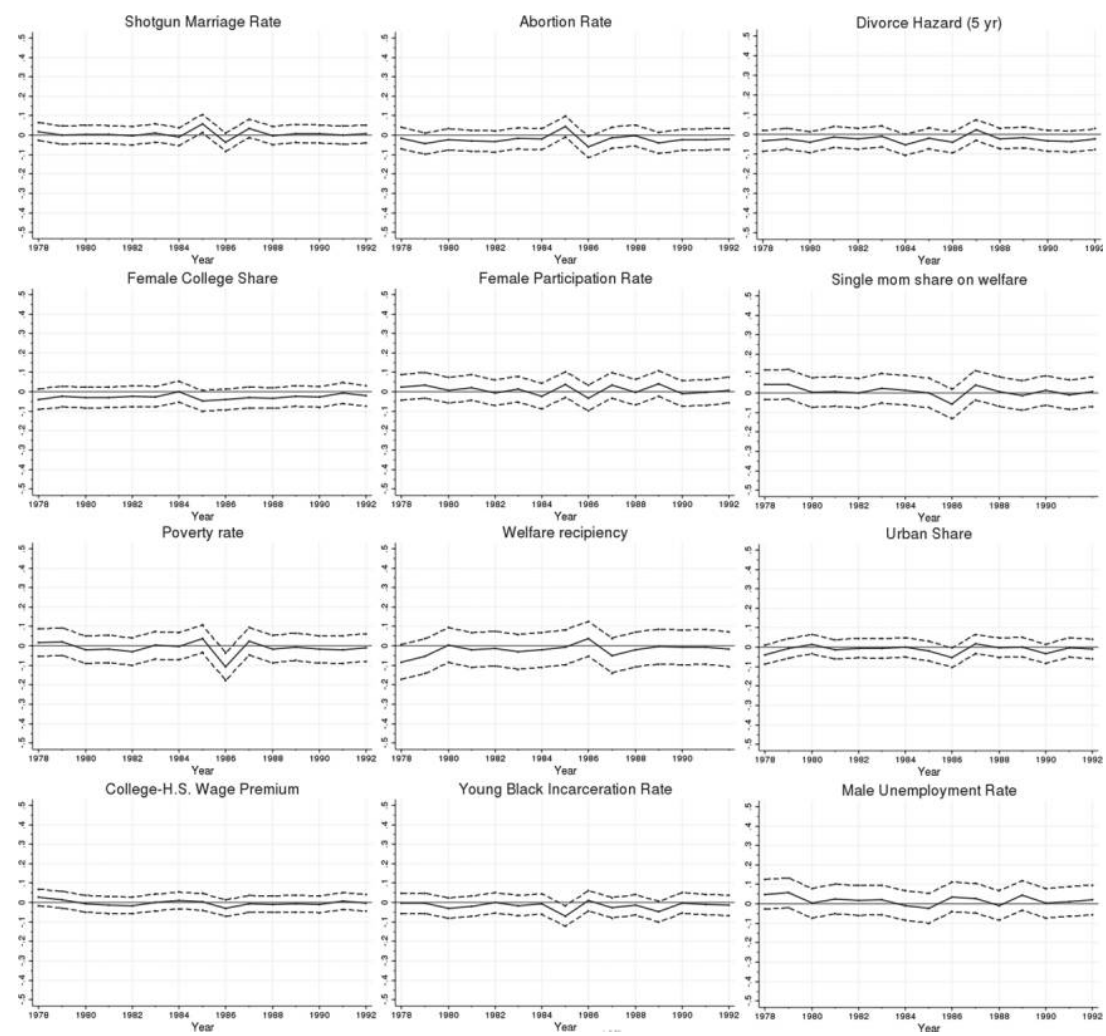

Young Black Incarceration Rate

Male Unemployment Rate

FIG. 5.-Child support legislation changes regressed on baseline state characteristics, 1977-92. I regress changes in the child support index on state-specific baseline characteristics interacted with time dummies, controlling for state and time fixed effects. The graphs plot estimates $\hat{\psi}_{t}$ from the regression equation $\Delta C S_{s t}=$ $\alpha+\psi_{t}^{\prime} w_{s, 1977}+\eta_{s}+\xi_{t}+\epsilon_{s t}$. The vector $w_{s, 1977}$ are baseline (1977) characteristics from each state (except for the black incarceration rate, for which the baseline year is 1980, and the abortion rate, for which the baseline year is 1978), and $\Delta C S_{s t}=$ $C S_{s t}-C S_{s, t-1}$. Each $w_{s, 1977}$ is standardized to have mean 0 and standard deviation 1. A color version of this figure is available online.

where $I n c_{i s t}$ is an indicator taking a value of 1 if person $i$ receives any child support income in year $t$; $C S_{s, t-a-1}$ represents the child support law index at time $t-a-1$, where $t$ is the survey year and $a$ is the age of her youngest child; and $s$ is the state of residence. ${ }^{31}$ The state of residence at the time of the survey is assumed to be the state of residence at the time of the youngest child's birth (an assumption explored in app. B). The vector $x_{i s t}$ represents

${ }^{31}$ I use the age of the youngest child because child support laws have strengthened over time, and these laws are most likely to impact child support receipt in the case of a mother's most recent child. 
individual controls, including age, age squared, age at the time of first birth, race indicators, dummies for three education categories (high school degree, some college, and college degree or more), and number of children dummies; $w_{s t}$ is a vector of state-year controls; and $\epsilon_{i s t}$ is an error term representing the unobserved determinants of child support receipt. Throughout the paper, standard errors are clustered at the state level and are robust to heteroskedasticity.

In this regression we expect the sign of $\beta_{1}$ to be positive, indicating that the adoption of a child support law has a positive effect on the fraction of women reporting child support income receipt. Table 4 indicates that this is indeed the case. Since the child support index is constructed with nine laws, we can interpret the coefficient as representing the effect of moving from a regime

Table 4

Child Support Laws' Effect on Child Support Receipt (1977-92)

\begin{tabular}{|c|c|c|c|c|c|c|}
\hline & \multicolumn{6}{|c|}{ Any Child Support Income } \\
\hline & (1) & (2) & (3) & (4) & $(5)$ & (6) \\
\hline Child support law index & $\begin{array}{l}.128 * * * \\
(.018)\end{array}$ & $\begin{array}{l}.140 * * * \\
(.014)\end{array}$ & $\begin{array}{l}.053 * * * \\
(.017)\end{array}$ & $\begin{array}{l}.052 * * * \\
(.017)\end{array}$ & $\begin{array}{l}.054 * * * \\
(.017)\end{array}$ & $\begin{array}{l}.053 * * \\
(.020)\end{array}$ \\
\hline Age at survey & $\begin{array}{l}.029 * * * \\
(.003)\end{array}$ & $\begin{array}{l}.029 * * * \\
(.003)\end{array}$ & $\begin{array}{l}.022 * * * * \\
(.002)\end{array}$ & $\begin{array}{l}.022 \% * \% \\
(.002)\end{array}$ & $\begin{array}{l}.022 * * * \\
(.003)\end{array}$ & $\begin{array}{l}.021 \% * * \\
(.003)\end{array}$ \\
\hline Age at first birth & $\begin{array}{l}-.005^{* \% *} \\
(.001)\end{array}$ & $\begin{array}{l}-.005 \% * \% \\
(.001)\end{array}$ & $\begin{array}{c}-.000 \\
(.001)\end{array}$ & $\begin{array}{r}-.000 \\
(.001)\end{array}$ & $\begin{array}{r}-.000 \\
(.001)\end{array}$ & $\begin{array}{r}-.000 \\
(.001)\end{array}$ \\
\hline African American & $\begin{array}{l}-.050 \% * \% \\
(.013)\end{array}$ & $\begin{array}{l}-.068^{* * *} \\
(.011)\end{array}$ & $\begin{array}{l}-.065 * * * \\
(.011)\end{array}$ & $\begin{array}{c}-.065^{* * * \%} \\
(.011)\end{array}$ & $\begin{array}{l}-.065^{* * * x} \\
(.011)\end{array}$ & $\begin{array}{l}-.065^{2 * 2 *} \\
(.011)\end{array}$ \\
\hline Other race/ethnicity & $\begin{array}{c}-.039 * \\
(.020)\end{array}$ & $\begin{array}{c}-.031 \\
(.020)\end{array}$ & $\begin{array}{c}-.033 * \\
(.019)\end{array}$ & $\begin{array}{r}-.032 \% \\
(.019)\end{array}$ & $\begin{array}{c}-.023 \\
(.018)\end{array}$ & $\begin{array}{c}-.027 \\
(.020)\end{array}$ \\
\hline High school degree & $\begin{array}{l}.056^{* * * *} \\
(.008)\end{array}$ & $\begin{array}{l}.049 * * * \\
(.007)\end{array}$ & $\begin{array}{l}.050 * * * \\
(.007)\end{array}$ & $\begin{array}{l}.049 * \cdots * \\
(.007)\end{array}$ & $\begin{array}{l}.050 * * * \\
(.007)\end{array}$ & $\begin{array}{l}.049 * * * \\
(.008)\end{array}$ \\
\hline Some college & $\begin{array}{l}.077^{* * * *} \\
(.010)\end{array}$ & $\begin{array}{l}.078 * * * \\
(.011)\end{array}$ & $\begin{array}{l}.075^{* * * *} \\
(.011)\end{array}$ & $\begin{array}{l}.075^{* * * \%} \\
(.011)\end{array}$ & $\begin{array}{l}.075^{* * *} \\
(.011)\end{array}$ & $\begin{array}{l}.077^{* * *} \times \\
(.011)\end{array}$ \\
\hline College degree & $\begin{array}{l}.097 * * * \\
(.014)\end{array}$ & $\begin{array}{l}.097^{* * * *} \\
(.013)\end{array}$ & $\begin{array}{l}.094 * * * \\
(.014)\end{array}$ & $\begin{array}{l}.094 * * \% \\
(.014)\end{array}$ & $\begin{array}{l}.093 * * * \\
(.014)\end{array}$ & $\begin{array}{l}.091 \% * * \\
(.014)\end{array}$ \\
\hline State fixed effects & & Yes & Yes & Yes & Yes & \\
\hline Year fixed effects & & & Yes & Yes & Yes & \\
\hline State-year controls & & & & Yes & Yes & \\
\hline Baseline controls $\times t$ & & & & & Yes & \\
\hline State-year fixed effects & & & & & & Yes \\
\hline Observations & 24,565 & 24,565 & 24,565 & 24,219 & 22,776 & 24,565 \\
\hline$R^{2}$ & .036 & .053 & .058 & .058 & .059 & .116 \\
\hline Mean of dependent variable & .17 & .17 & .17 & .17 & .17 & .17 \\
\hline
\end{tabular}

NoтE.-The sample is from the March Current Population Survey and is restricted to never-married mothers between 17 and 60 with a child 18 years or less in the household whose father is reported absent from the household. The dependent variable is an indicator for whether the mother receives any child support income at time $t$. The right-hand-side variable of interest is an index of child support laws in the mother's state in the year prior to the birth year of the youngest child, where the index is constructed using the Case-McLanahan data, 1977-92. Controls included but not reported are as follows: age, age squared, age at birth, race dummies, education dummies, and number of children dummies. Column 6 includes interacted state-year fixed effects. Standard errors are clustered at the state level.

$* p<.10$
$* * p<.05$

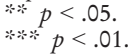


with none of the laws in place to one with all nine laws on the probability of receiving child support income. These laws increased the probability of child support receipt by $5.3 \%$, as shown in the specification with state and year fixed effects (col. 3). Adding additional time-varying state controls (col. 4) and baseline (1977) state-level controls interacted with time trend (col. 5) do not reduce the magnitude of the laws' effect. Given that the fraction of the sample reporting child support income is $17 \%$, the magnitude of the laws' cumulative effect is quite large.

We might be concerned that states that adopt stronger child support laws have a population of individuals more likely to comply with such laws; in this case, $\beta_{1}$ may reflect state-year-specific attitudes toward the legal system or child support laws rather than the effect of the laws per se. Because there is variation within state-year cells in the age of the youngest child, it is possible to include interacted state-year fixed effects, which controls for statelevel time trends in attitudes toward child support that might lead to greater compliance. The identifying variation in this specification is variation in laws at the time of birth of the youngest child within a state-year cell, and the estimated effect is quite similar, reported in column 6 of table 4. Other coefficients may be of interest as well: from table 4 we see that older, higher educated, and nonminority mothers are more likely to report having received child support income.

How much income did the laws generate for single-mom households? We saw in figure 2 that conditional on receiving any child support income, the average amount received per never-married mother is between $\$ 2,000$ and $\$ 3,000$, valued in 2000 USD. However, there may be some crowd-out in public assistance income due to policies limiting the pass-through of child support for women receiving public benefits (Cancian and Meyer 2005). In table B.4, I explore the crowd-out of public assistance and Supplemental Security Income receipt for the March CPS sample of never-married mothers. I find that the child support rollout reduced average per-person public assistance from the government by $\$ 250-\$ 500$ annually (also in 2000 USD). Hence, the net benefit of child support is still large as a percentage of income. ${ }^{32}$

\section{Abortion}

In this section I consider the effect of the child support rollout on the abortion rate. The mechanism highlighted in the model is that child support reduces the financial burden of raising a child as a single mom, and women

${ }^{32}$ About $15 \%$ of child support recipients receive AFDC or Temporary Assistance for Needy Families (TANF), and this fraction has remained relatively stable over the sample period (Cancian and Meyer 2005). Note that crowd-out of public assistance will take place only during the time the mother is eligible for and receiving AFDC/TANF, while single mothers may receive child support throughout the child's first 18 years, and sometimes longer. 
will abort fewer pregnancies as a result. Note that abortion became legal in all US states several years before the child support rollout, following the 1973 Supreme Court decision Roe v. Wade.

The dependent variable used in the regression analysis that follows is the state-year abortion rate, which is defined as the total number of abortions per 1,000 women aged $15-44 .{ }^{33}$ I estimate the following regression:

$$
a_{s t}=\beta_{0}+\beta_{1} C S_{s t}+\gamma^{\prime} w_{s t}+\epsilon_{s t} .
$$

All specifications include both state and year fixed effects. Cells are weighted by the state's population of 15-44-year-old women. A potential source of bias in estimating equation (3) is that trends in state-level attitudes toward abortion may be correlated with the pattern of the child support rollout. To mitigate this concern, I include a proxy for societal attitudes toward abortion using data from the GSS, which is the principal factor from a factor analysis of the nine abortion-related questions in the GSS and is aggregated to the region-year level. ${ }^{34}$ Because of gap years in both the Guttmacher and GSS data and to prevent the regressions from dropping observations due to missing data, I impute values for gap years using the midpoint of the lead and lag values for each state-year. ${ }^{35}$

Table 5, columns $1-4$, presents the main results, adding additional controls in each successive column. The full set of child support laws adopted over the 1978-92 period is associated with a decline in the abortion rate by 1.8-3.1, off a base of 27.6. The preferred specification is column 4, which includes controls for abortion attitudes, state-year controls, and baseline state controls interacted with a linear time trend. Over the sample period 197892 , the mean policy index increased by .637 . If we scale the point estimate (which represents a change from 0 to 1 in the policy index) by the actual growth in the policy index over this period, the effect size ranges from 1.15 to 1.97 .

The magnitude of the estimates in columns 1-4 implies that the child support rollout led to a decline in abortions by $4 \%-7 \%$ over the sample period, suggesting that child support legislation has played a significant role in the recent decline of abortions in the United States. To provide a sense of the magnitude, the abortion rate - that is, the number of abortions per 1,000 women aged 15-44 - declined roughly 2.5 over the 1978-92 period, meaning that child support can account for more than $46 \%$ of the decline over this period.

${ }^{33}$ Using the log total abortions as the dependent variable produces similar results.

${ }^{34}$ The societal attitudes factor correlates strongly with the number of abortion providers per capita, which can be seen formally in table B.3. This correlation with an objective measure of abortion availability suggests that the GSS survey data represent a meaningful proxy for abortion attitudes.

35 The estimates are not sensitive to this imputation, and the results from the estimation of eq. (3) with nonimputed data are presented in table B.7. 
Table 5

Effect of Child Support Laws on Abortions (1978-92)

\begin{tabular}{lcccccc}
\hline & $(1)$ & $(2)$ & $(3)$ & $(4)$ & $(5)$ & $(6)$ \\
\hline Child support index & $-.3 .059^{* *}$ & $-2.956^{* *}$ & $-2.571^{* *}$ & $-1.855^{* *}$ & $-2.059^{*}$ & -1.802 \\
& $(1.270)$ & $(1.254)$ & $(1.135)$ & $(.915)$ & $(1.048)$ & $(1.124)$ \\
Abortion attitudes control & & Yes & Yes & Yes & Yes & Yes \\
State-year controls & & & Yes & Yes & Yes & Yes \\
Baseline controls $\times t$ & & & & Yes & Yes & Yes \\
Abortion providers control & & & & & Yes & \\
Region $\times t$ & & & & & & Yes \\
Number of observations & 720 & 720 & 720 & 720 & 720 & 720 \\
$R^{2}$ & .979 & .979 & .979 & .981 & .982 & .981 \\
Mean of dependent variable & 27.55 & 27.55 & 27.55 & 27.55 & 27.55 & 27.55 \\
\hline
\end{tabular}

NoTE.-The dependent variable is number of abortions per 1,000 women aged 15-44, regressed on the child support law index. All specifications include state and year fixed effects. The abortion attitudes control is the principal factor from a factor analysis of the nine abortion-related questions in the General Social Survey, aggregated to the region-year level. Standard errors (in parentheses) are clustered at the state level.

$* p<.10$.

$* * p<.05$.

We might be concerned that trends in abortion availability are somehow correlated with trends in the child support rollout. For this reason, I control for the number of abortion providers per 100,000 women aged 15-44 in the state-year in the column 5 specification. Its inclusion does not affect the results. ${ }^{36}$

Column 6 includes interactions between region and each year separately; this specification allows for heterogeneity across regions in the time path of abortion rates. The standard errors increase as the regression loses power, and the coefficient on the child support index loses statistical significance at the $10 \%$ level. However, the point estimate changes only slightly, suggesting that a spurious correlation between region-specific trends in abortion rates and the time path of child support law adoption is not driving the main estimates presented in columns 1-4. In addition, an $F$-test of the null hypothesis that all interactions between region and year dummies are jointly equal to zero fails to reject the null $(F(8,47)=1.06$ and $p=.41)$.

As an additional check, in section C. 4 of appendix C I present a placebo exercise that explores whether future changes in child support laws predict current abortion rates. I reestimate equation (3) and include an additional control for the future change in $C S_{s t}$. I find that future changes in the law do not affect current abortion rates and that the main estimates are unaffected

${ }^{36}$ Including abortion providers in the regression has the advantage of controlling for a proxy measure of cost, as it captures the availability of abortions represented by the density of clinics in a state-year. Its inclusion, however, has the disadvantage of introducing a classic supply-demand endogeneity, because abortion providers may respond to unobserved shocks to demand captured by the error term. Hence, for all but col. 5 I omit this control. 
Table 6

Bounding Selection: Counterfactuals Using Nonpregnancies due to Child Support

\begin{tabular}{lcccccc}
\hline & & \multicolumn{5}{c}{$\begin{array}{c}\text { Percentile of Abortion Rate Assigned } \\
\text { to Nonpregnancies }\end{array}$} \\
\cline { 3 - 7 } & Baseline & Median & 60 th & 70 th & 80 th & 90 th \\
\hline Child support index & $-2.571 * *$ & $-2.129 *$ & $-2.062^{*}$ & $-2.043 *$ & $-2.001 *$ & -1.859 \\
& $(1.135)$ & $(1.138)$ & $(1.139)$ & $(1.139)$ & $(1.140)$ & $(1.141)$ \\
Abortion attitudes control & Yes & Yes & Yes & Yes & Yes & Yes \\
State-year controls & Yes & Yes & Yes & Yes & Yes & Yes \\
Number of observations & 720 & 716 & 716 & 716 & 716 & 716 \\
$R^{2}$ & .979 & .979 & .979 & .979 & .979 & .979 \\
Mean of dependent variable & 27.55 & 27.55 & 27.55 & 27.55 & 27.55 & 27.55 \\
\hline
\end{tabular}

NOTE.-This table assigns counterfactual abortion rates to pregnancies that are not observed in the data due to a direct effect of child support on fertility. These pregnancies are assigned abortion probabilities at the percentile (indicated at each column) in the initial (1978) state-level distribution. The baseline specification comes from table 5, col. 3. Standard errors (in parentheses) are clustered at the state level.

$* p<.10$.

$* p<.05$

by the inclusion of this control; I interpret these results as evidence against reverse causality driving the results in this section.

\section{Bounding Selection Bias}

The empirical results on fertility presented above suggest that child support laws may have reduced the probability of a nonmarital pregnancy. Any pregnancies that are not occurring may have higher or lower abortion rates than those that do occur. We might think, for instance, that child support reduces pregnancy among women most likely to abort, which would lead us to overstate the effect of the policy on abortion rates.

I perform pessimistic counterfactual scenarios to examine the extent of this bias and report these in table 6. As in the selection counterfactuals for marriage performed above, I assume that the full rollout of child support laws reduced total pregnancies by $2 \%$. I subsequently assign higher and higher abortion rates to these pregnancies, ranging from the 50th percentile to the 90th percentile in the initial year's state-level distribution. ${ }^{37}$ Under the counterfactual scenario in which these nonoccurring pregnancies have the 90th percentile of abortion rates, the estimate loses statistical significance at the $10 \%$ level. Hence, the negative effect on fertility would have to consist of women with some of the highest abortion rates for the results to disappear.

37 The expression for the imputed abortion rate is $\hat{a}_{s t}=a_{s t}+\left(.02 \times C S_{s t} \times\right.$ births $\left._{s, 1978}\right)\left(a_{1978}^{(p)} \times\left(1 /\right.\right.$ births $\left.\left._{s, 1978}\right)\right)$. The first term is the observed abortion rate, i.e., 
D. The Effect of Child Support Laws on the Marriage Decision

Because SIPP contains retrospective marital and fertility histories, we can construct a panel at the individual level, which we can use to identify the effect of child support laws on the probability of never-married women becoming married. The unit of observation is a person-year, and I restrict the sample to include women between ages 18 and 44 .

To avoid overweighting individuals who appear in the sample a greater number times, I weight each observation by their SIPP person weight multiplied by the reciprocal of the number of total observations for that person in the regression sample, so that each person's observation weights sum to her SIPP person weight. (This reweighting has a relatively minor effect on the estimates, and the unweighted regressions are reported in table B.5.) The main estimating equation is

$$
\begin{aligned}
\text { marry1st }_{i s t}= & \beta_{0}+\beta_{1} n m p r e g_{i s t}+\beta_{2} n m p r e g_{i s t} \\
& \times C S_{s t}+\beta_{3} C S_{s t}+\gamma^{\prime} x_{i s t}+\epsilon_{i s t},
\end{aligned}
$$

where $n$ mpreg $g_{\text {ist }}$ is an indicator for never-married woman $i$ becoming pregnant with her first-born child in year $t$. The variable marry $1 s t_{i s t}$ is an indicator for person $i$ becoming married for the first time in either year $t$ or year $t+1$. The variable $C S_{s t}$ represents the child support enforcement measure for state $s$ in year $t .{ }^{38}$ The vector of individual controls $x_{i s t}$ includes a high school completion dummy, race dummies, age dummies, and SIPP sample year dummies. I omit higher education categories from the regression controls because the decision to get married may affect educational attainment, and their inclusion would introduce a simultaneity bias. All specifications include state fixed effects and year fixed effects, which remove state and year means in the propensity to marry.

The coefficient $\beta_{1}$ in equation (4) represents the effect of having a nonmarital pregnancy in year $t$ on the individual's decision to get married in year $t$ or $t+1$ relative to those who are not pregnant (or who miscarry or have an abortion). The coefficient of interest is $\beta_{2}$, which represents the difference in difference: the effect of strengthened child support enforcement on marriage

total abortions per 1,000 women in state-year st. The second term is the selection term: total pregnancies unobserved due to the policy (proxied with births) multiplied by the number of abortions per pregnancy (again proxied with births), expressed per 1,000 women. The term $a_{1978}^{(p)}$ indicates the percentile $p$ in the 1978 state-level distribution used to compute the counterfactual.

${ }^{38}$ The respondent's state of residence at the time of the survey is assumed to be her state of residence in each year of the panel. This assumption requires there to be no selective migration by women who have a nonmarital pregnancy based on states' child support laws. I check this assumption in table B.8 and find no evidence for selective migration. 
for women who face a nonmarital pregnancy relative to women who do not, relative to this difference under weakened child support enforcement.

Without the inclusion of interaction terms between nmpreg $_{\text {ist }}$ and state, $n_{m p r e} g_{i s t}$ and $x_{i s t}$, and $n m p r e g_{i s t}$ and year, the identification assumption is that the propensity to marry following a nonmarital pregnancy does not vary with state, demographics, or year. This assumption can be relaxed by including the full set of interactions, and these specifications are reported in the main results table. However, the considerable number of interactions results in a loss of degrees of freedom, and, as will be seen in the next section, the main effect, while remaining similar in magnitude, loses statistical significance in the most flexible specification. For this reason, in the baseline regressions I rely on the stronger identifying assumption, but in the interest of both completeness and transparency I report the specifications requiring weaker assumptions.

\section{Assessing the Difference-in-Differences Design}

The difference-in-differences design is motivated by the idea that after controlling for state and time effects, the precise timing and geography of the rollout of child support laws are uncorrelated with unobserved determinants of individual choices regarding marriage and fertility.

There are three main challenges for identification in this setting. The first is reverse causality: that changes in unobserved attitudes regarding marriage and fertility may be a driving force behind child support statute adoption. For example, a declining attitude toward marriage may affect the desire to have stronger protections for children of unmarried couples and therefore lead to stronger child support enforcement. I present empirical evidence in section V.A (above) against this hypothesis. As a second check, I estimate a placebo regression that adds interactions between pregnancy and changes in a state's future child support law. This specification tests whether current marital choices predict future changes in child support, as they would if the reverse causality story were in effect. This exercise is discussed in section C.2 of appendix C, and the results are reported in table C.2. I do not find evidence in favor of reverse causality.

The second concern for identification is that of omitted variables: if statelevel time trends such as expanded work opportunities for women or the absence of marriageable men due to incarceration affects both marriage rates and trends in child support legislation, the main estimates will be biased. To mitigate the concern that the estimated effect is driven by unobservables, I report results with and without a large set of time-varying controls. First, I control directly for societal attitudes at the region-year level, which proxy for public sentiment on issues including premarital sex, sex education, abortion, and the generosity of public assistance. Next, I add time-varying state controls, including percent black in the population, the male unemployment 
rate, the share of college graduates who are female, the female labor force participation rate, urban share of households, share of welfare recipiency, share of single moms on welfare, and the share of people below $100 \%$ of the federal poverty line. Third, I show that the estimates are robust to specifications allowing for differential time trends related to baseline state-level characteristics. Fourth, I show that the estimates are robust to the inclusion of interacted state-year fixed effects, along with interactions of all right-hand-side variables with state dummies and time dummies. This last specification relies on variation across women in pregnancy status within state-year cells and has the advantage of holding fixed all state-level time-varying determinants of marriage that may be correlated with the timing of child support enactments. All of these specifications are presented in the main results table, for ease of comparison across specifications.

The third challenge for identification is that the timing of pregnancy is to some extent a choice, as is explicitly captured in the model of section III. Hence, equation (4) faces a selection concern. I defer this discussion until section V.D, after presenting estimates of the direct effect of child support enforcement on fertility. For now, it is worth emphasizing that in order to give the estimates of equation (4) a causal interpretation, we must assume that child support laws do not cause differential selection into pregnancy based on underlying propensity to marry. In the model of section III, indeed there is differential selection based on propensity to marry, but the selection works against finding a negative coefficient $\beta_{2}$ : couples who are least likely to marry decrease their fertility the most, implying that a selection effect would make child support appear to increase the propensity to marry.

\section{Event Study Illustration}

Figure 6 provides a graphical depiction of the identification strategy, represented as an event study. Since the child support index is a continuous variable, it is useful to recenter the data so that time 0 represents the biggest change in the child support index for each state after removing state and year fixed effects. We then plot the outcome variables and controls relative to this "event." All figures discussed here include only the sample of states (35 of 48) for which we can construct a balanced time series of 3 years before and after the biggest change, so that changes in the series are not driven by changes in the composition of states included in the sample. Figures without this compositional adjustment look very similar and are presented in appendix B. The child support series of all panels of figure 6 show a sharp increase in the child support residual between time -1 and $0 .{ }^{39}$

${ }^{39}$ Note that what appears to be a decline in the child support index approaching year $\mathrm{O}$ is a consequence of the regression mechanics, which forces the residuals to sum to zero across time periods. 

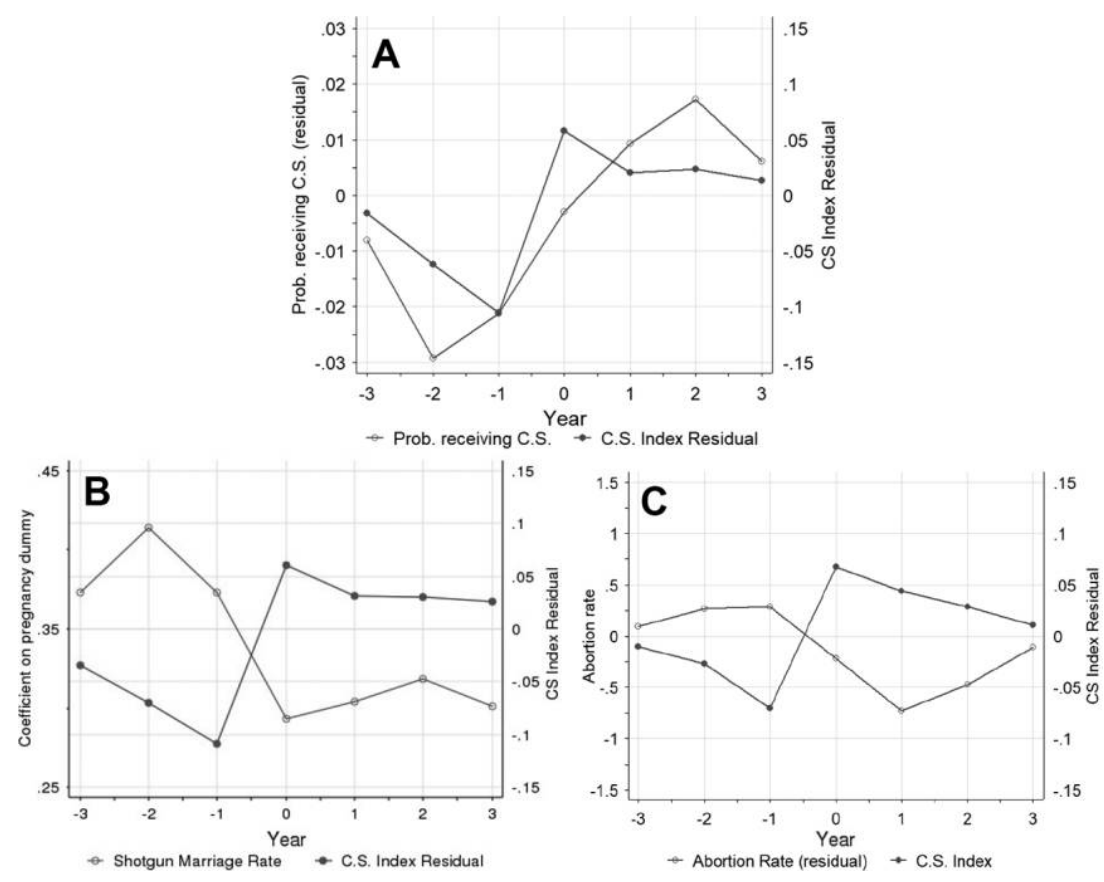

FIG. 6.-Event study illustration of the difference-in-differences design. $A$ presents the first stage as an event study. For each state I recenter the data so that both cause and effect occur at time 0 . For the child support policy index (right $Y$-axis), time 0 represents the year with the strongest growth in the policy index in each state, after removing state and year fixed effects. For the child support income series (left $Y$-axis), I regress the probability of receiving child support on controls, with state and survey year fixed effects. I then plot the mean residuals in the recentered year, where year 0 represents the year after the policy change. $B$ and $C$ present the policy index series, constructed exactly as in $A$. For the marriage series and abortion series, time 0 represents the year after the biggest change in the policy index. The marriage series $(B)$ is constructed as follows: in each recentered year, I regress the marriage dummy on a dummy for pregnancy and controls for the sample of women who experience a nonmarital pregnancy; the graph plots the coefficients in each recentered year. $C$ plots mean residuals, in each recentered year, from a regression of the abortion rate on state and year fixed effects. The range of the right $Y$-axis is 1 standard deviation of the child support index; the range of the left $Y$-axis is 1 standard deviation of the abortion rate variable. The panels include 35 out of 48 states for which we can construct a balanced sample 3 years before and after the biggest jump in the legal index. A color version of this figure is available online.

To construct the shotgun marriage series, depicted in figure $6 B$, I regress a marriage dummy (equal to 1 if the person marries in the current year or the next year) on a pregnancy dummy, along with state and year fixed effects and individual controls (race dummies, age, age squared, and a high school 
degree dummy), separately in each "recentered" year. The regression sample includes women in the 18-44 age cohort whose first pregnancy was outside marriage. I then plot the coefficient estimate on the pregnancy dummy in each year, so that time 0 represents the year after the biggest jump in child support residual. We see from the figure that the increase in the child support law index from year -1 to 0 is associated with a substantial decline in the probability of marriage following a nonmarital pregnancy.

To construct the abortion series, presented in figure 6C, I first remove year and state fixed effects from the abortion rate. I then plot the mean of these residuals in each recentered year. Again, for the abortion rate series, time 0 represents 1 year after the biggest jump in the child support law index (stripped of state and year fixed effects). The figure shows a decline in the abortion rate following an increase in child support enforcement, supporting the findings of section V.C. ${ }^{40}$

We can contrast figure 6 with event study plots using control variables. The research design requires no sharp changes in unobserved determinants of shotgun marriages around the "event." If, for example, sharp changes in female labor market opportunities took place at the same time as the child support rollout, we would be concerned about omitted variables. Figure 7 depicts the event study with several other variables on the left $Y$-axis, after removing state and year fixed effects: the female labor force participation rate, the female college share, the fraction of residents on welfare, and the fraction of residents below the $100 \%$ federal poverty line. Note that there do not appear to be any sharp changes around the biggest change in child support laws. This is reassuring, and it lends support to the research design, which requires common trends in unobserved determinants of shotgun marriages. Similar pictures for additional controls and for the GSS societal attitudes data are presented in figures B.2 and B.3 (figs. B.1-B.5 are available online).

\section{Marriage Results}

Table 7 reports the results from the estimation of equation (4). Column 1 reports estimates using state and year fixed effects. Column 2 includes regionyear societal attitudes controls, including the principal factor from a factor analysis of the nine abortion-related questions in the GSS and four additional variables controlling for attitudes toward federal welfare, sex education, divorce, and premarital sex. Column 3 includes additional state-year controls. Column 4 includes baseline (1977) controls (including societal attitude controls) interacted with linear time trends. The results are remarkably stable

${ }^{40}$ Note that the child support series in fig. $6 \mathrm{~B}$ is slightly different from its counterpart in fig. $6 \mathrm{C}$. The reason is that the abortion data has gap years, and hence the variation in the child support series used for identification is slightly different for the two outcome variables. 

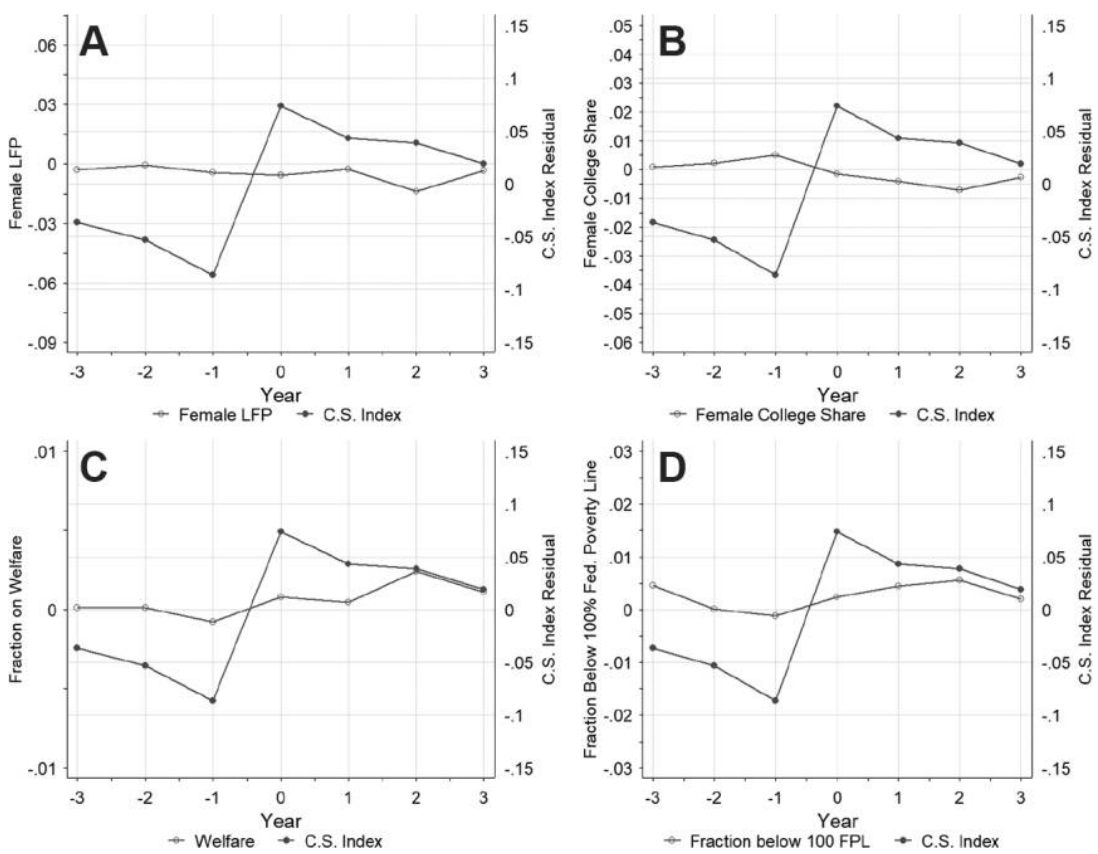

FIG. 7.-Event study illustration: other variables. This figure repeats the exercise of figure 6 with alternative state-level variables depicted on the left $Y$-axis. The range of the left $Y$-axis is 2 standard deviations of the left $Y$-axis variable. FPL $=$ federal poverty line; LFP = labor force participation. A color version of this figure is available online.

across specifications. In the first four columns, the coefficient on the interaction term nmpreg $_{i s t} \times C S_{\text {st }}$ is negative and significant, with estimates between -.117 and -.120 . These coefficients indicate that a woman who has a nonmarital pregnancy in a state-year that has all child support laws in place compared with a nonmarital pregnancy in a state-year with none is about 12 percentage points less likely to have a shotgun marriage. These estimates are relative to a $38 \%$ baseline likelihood of becoming married in the same year or in the year following a nonmarital pregnancy, which can be seen in the coefficient in the second row.

Note that the regressions in columns $1-4$ do not include interactions between $n$ mpreg $g_{i s t}$ and state, $x_{i s t}$, or year. This means that these regressions are estimated under the assumption that the propensity to marry following a nonmarital pregnancy does not vary with state, $x_{i s t}$, or year after conditioning on controls.

Column 5 reports the results including interactions between $n m p r e g_{i s t}$ and state dummies and between $n$ mpreg $g_{i s t}$ and $x_{i s t}$, flexibly allowing for women in different states and demographics to have different propensities to marry following a nonmarital pregnancy. The point estimate is -.154 


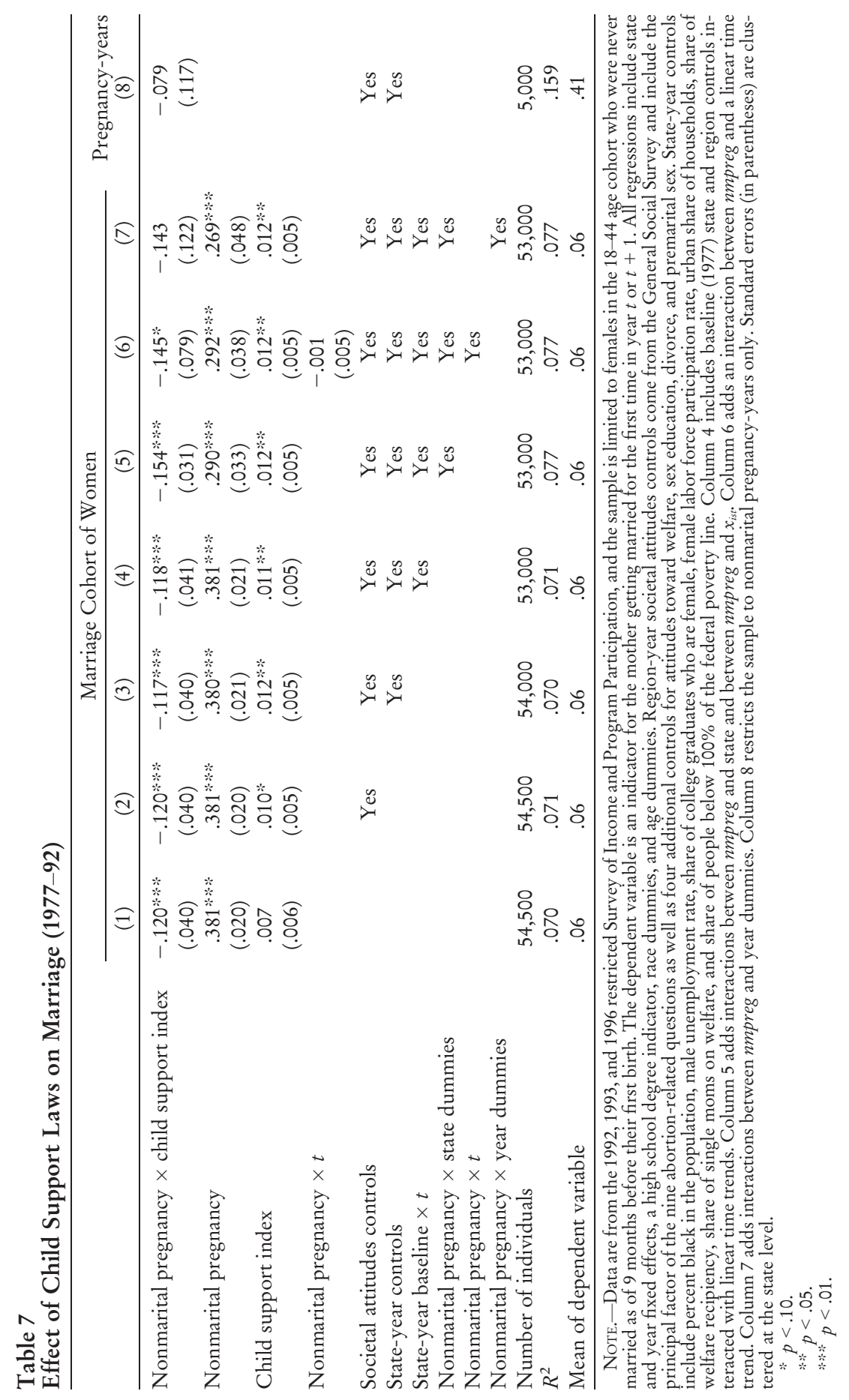


and is significant at the $1 \%$ level. Column 6 adds an interaction between $n_{m}$ preg $_{\text {ist }}$ and a linear time trend; the point estimate is -.145 , and the estimate remains significant at the $10 \%$ level. The point estimate diminishes only slightly, mitigating concern for bias due to a violation of common trends. Note that the coefficient estimate on $n$ mpreg $g_{i s t} \times t$ is quite small in magnitude and statistically insignificant. This economically small effect size lends support to the prior specifications that assume propensity to marry evolves in the same way for women who are pregnant and those who are not.

Column 7 adds interactions between mmpreg $_{\text {ist }}$ and all year dummies, flexibly allowing for propensity to marry following a pregnancy to vary with each year in the sample. The regression loses considerable power and the standard errors become large. The main effect is no longer significant, but the effect size remains similar in magnitude at -.143 . An $F$-test of the null hypothesis that all interactions between $n m p r e g_{i s t}$ and year dummies are jointly equal to zero fails to reject the null $(F(20,40)=1.458$ and $p=.170)$, mitigating concern that the main estimate is driven by time trends in the propensity to marry following a pregnancy.

Column 8 restricts the sample to pregnancy-year observations, meaning I restrict the sample to observations with $n$ mpreg $=1$. By restricting to these observations, we are effectively allowing state and time trends in the propensity to marry following a nonmarital pregnancy. The coefficient on the interaction term-reported in the top row for ease of comparison with the estimates in other columns - remains negative, but the standard errors are quite large, and in this specification we fail to reject a null effect.

Taken together, the results suggest that moving from a regime with none of the child support laws in place to one with all of them in place leads to about a 12 percentage point reduction in the shotgun marriage rate, off a base of $38 \%$. Over the sample period, the policy index increased from an average of .13 (in 1977) to .79 (in 1992). Scaling the column 3 point estimate by the actual growth in the policy index over this period delivers an effect size of $.117 \times(.79-.13)=.077$ percentage points. This effect size is quite large relative to the $\sim 10$-point decline in the shotgun marriage rate over the 1977-92 sample period. ${ }^{41}$

The magnitude of the estimated effect may appear large given the substantial amount of nonpayment of child support. It is worth pausing to re-

${ }^{41}$ Table B.6 examines heterogeneity by the type of policy adopted, reestimating eq. (4) and replacing the policy index with a separate indicator for each policy and replacing the policy index interaction term with interactions of each policy with the pregnancy indicator. The policies that are statistically and economically significant are the genetic testing and wage-withholding provisions. Less important policies for the marriage decision are penalties for failure to pay (such as allowing liens on property). 
flect on the plausibility of such large effects. First, it is important to note that the effect can be large due to a substantial number of couples on the margin of indifference between marriage and remaining single; in this case, a small reward for not marrying can have a substantial effect on aggregate marriage rates. The marriage decision following a nonmarital pregnancy was chosen for this analysis precisely because they are marginal marriages in which couples are likely to exhibit a high elasticity with respect to marital incentives. Second, the estimates reported here are consistent with what other authors have reported; for example, Rossin-Slater (2017) studies in-hospital voluntary paternity establishments and finds that for each additional paternity established there are 0.13 fewer parental marriages after childbirth. In addition, if paternity establishment gives fathers greater custodial rights outside marriage, as discussed in appendix A, marriage decisions may be affected even if a large fraction of established fathers are subsequently delinquent on payments.

\section{Marriage Results: Selection into Fertility}

Let us now return to the discussion of selection into fertility raised in section V.D. To restate the selection issue, it is plausible that child support affects only fertility and not marriage; under this interpretation, the effects on marriage observed in section V.D occur because individuals who are most affected in their fertility also happen to be those most likely to marry following a pregnancy.

First, it should be noted that the literature has found that young and loweducated men and women reduce their fertility the most in response to child support legislation, while older and more educated individuals have little response (Aizer and McLanahan 2006; Plotnick et al. 2007). But older and higher-educated men and women have far higher rates of shotgun marriage than those who are younger and less educated, meaning selection works against finding a negative effect of child support on marriage. The theoretical model in this paper supports the prior literature: couples who are least likely to marry reduce their fertility the most, again suggesting that the empirical effects estimated on marriage in section V.D are a lower bound of the true effect.

To examine the sensitivity of the marriage estimates to selection bias, I follow Bharadwaj, Loken, and Neilson (2013) and perform an exercise that offers pessimistic counterfactual scenarios; these results are reported in table 8 . To construct the counterfactuals, I begin by assuming that the full rollout of child support laws reduced total pregnancies by $2 \%$, a large effect. Next, I impute "excess birth" that would have occurred absent the policy. Specifically, I impute an additional $\Delta C S_{s t} \times .02$ births to single women in each state-year: these are the births that are not observed due to the policy change 
Table 8

Placing Bounds on Selection: Counterfactuals Using Nonpregnancies due to Child Support

\begin{tabular}{|c|c|c|c|c|c|}
\hline & \multirow[b]{2}{*}{$\begin{array}{l}\text { Baseline } \\
\text { (1) }\end{array}$} & \multicolumn{4}{|c|}{$\begin{array}{l}\text { Shotgun Marriage Rate Assigned } \\
\text { to Imputed Pregnancies }\end{array}$} \\
\hline & & $\begin{array}{c}50 \% \\
(2)\end{array}$ & $\begin{array}{c}60 \% \\
(3)\end{array}$ & $\begin{array}{c}70 \% \\
(4)\end{array}$ & $\begin{array}{c}90 \% \\
(5)\end{array}$ \\
\hline $\begin{array}{l}\text { Nonmarital pregnancy } \times \text { child } \\
\text { support index }\end{array}$ & $\begin{array}{l}-.117 * \% * \\
(.040)\end{array}$ & $\begin{array}{l}-.112^{* * * *} \\
(.039)\end{array}$ & $\begin{array}{l}-.112 \% * \% \\
(.040)\end{array}$ & $\begin{array}{l}-.111 * \% \\
(.042)\end{array}$ & $\begin{array}{l}-.111 * * \\
(.041)\end{array}$ \\
\hline Nonmarital pregnancy & $\begin{array}{l}.380 \% * \% \\
(.021)\end{array}$ & $\begin{array}{l}.379 * * * \% \\
(.020)\end{array}$ & $\begin{array}{l}.380 \% * \% \\
(.020)\end{array}$ & $\begin{array}{l}.382^{* * * \%} \\
(.021)\end{array}$ & $\begin{array}{l}.387 * \cdots * \\
(.021)\end{array}$ \\
\hline Child support index & $\begin{array}{l}.009 \\
(.006)\end{array}$ & $\begin{array}{l}.009 * \\
(.006)\end{array}$ & $\begin{array}{l}.010 \% \\
(.006)\end{array}$ & $\begin{array}{l}.010 * \\
(.006)\end{array}$ & $\begin{array}{l}.010 * \\
(.006)\end{array}$ \\
\hline Societal attitudes controls & Yes & Yes & Yes & Yes & Yes \\
\hline State-year controls & Yes & Yes & Yes & Yes & Yes \\
\hline Number of individuals & 54,000 & 54,000 & 54,000 & 54,000 & 54,000 \\
\hline$R^{2}$ & .070 & .071 & .071 & .072 & .072 \\
\hline Mean of dependent variable & .05 & .05 & .05 & .05 & .05 \\
\hline $\begin{array}{l}\text { NoтЕ.-This table assigns count } \\
\text { due to a direct effect of child suppo } \\
\text { duced nonmarital births by } 2 \% \text {. I } \\
\text { state-year. These pregnancies are rar } \\
\text { gression specification comes from ta } \\
\text { parentheses) are clustered at the stat } \\
* p<.10 \text {. } \\
* * p<.05 \text {. } \\
* * * 0<<.01 \text {. }\end{array}$ & $\begin{array}{l}\text { tual marria } \\
\text { nfertility. } \\
\text { impute an } \\
\text { ly assigned } \\
\text { ccol. } 3 \text {, and } \\
\text { ell. }\end{array}$ & $\begin{array}{l}\text { ates to } p \\
t \text { by ass } \\
\text { litional } \\
\text { rriage rat } \\
\text { columns }\end{array}$ & $\begin{array}{l}\text { ncies tha } \\
\text { that the } \\
\times .02 \mathrm{bi} \\
\text { licated at } \\
\mathrm{w} \text { this sp }\end{array}$ & $\begin{array}{l}\text { not obser } \\
\text { child sup } \\
\text { o single } \\
\text { column h } \\
\text { tion. Star }\end{array}$ & $\begin{array}{l}\text { in the data } \\
\text { rollout re } \\
\text { en in each } \\
\text { ng. The re } \\
\text { derrors (in }\end{array}$ \\
\hline
\end{tabular}

under the selection story ${ }^{42}$ I then randomly assign higher and higher shotgun marriage rates to these imputed births- $60 \%, 70 \%$, and so on-and reestimate the main specification of the marriage regression (col. 3 of table 7). The exercise shows that even when imputing large selection effects, the main effect on marriage is only slightly diminished. Even under the counterfactual scenario in which these nonoccurring pregnancies have $90 \%$ marriage rates, the estimates are statistically significant at the $10 \%$ level. The point estimates remain consistent with the interpretation that child support has reduced marriage following a nonmarital pregnancy.

\section{Conclusion}

This paper presents both a model and empirical evidence to understand the effect of child support policies on selection into marriage and fertility. The model shows that child support enforces commitment from men to future transfers in the event of a child and crowds out the commitment role

${ }^{42}$ Note that $\Delta C S_{\text {st }} \times .02$ is the appropriate fraction since it implies, once we sum over the years, that the full rollout would have affected fertility rates by a fraction $\sum_{t=1972}^{1992} \Delta C S_{s t} \times .02=.02 \times\left(C S_{s, 1992}-C S_{s, 1992}\right)$ in each state. 
of marriage. Child support also reduces abortions because of the diminished cost of raising the child as a single mom. The empirical evidence uses variation in the state-year rollout of child support laws over the 1977-92 period relative to the timing of nonmarital pregnancy; I show that the rollout led to a reduction in the probability of having a shotgun marriage and a decline in the abortion rate.

The main takeaway is that child support laws, which are intended to ensure that the noncustodial parent contributes to child-rearing, have important consequences for selection into fertility and marriage. The magnitudes estimated in this paper suggest that the increase in child support enforcement can account for a substantial part of the long-run decline of shotgun marriages and part of the recent fall in the abortion rate. Child support laws are thus central to understanding major trends in marriage and fertility in the second half of the 20th century, during which child support enforcement went from virtual nonexistence to automatic and near universal.

\section{References}

Aizer, Anna, and Sara McLanahan. 2006. The impact of child support enforcement on fertility, parental investments, and child well-being. Lournal of Human Resources 41, no. 1:28-45.

Akerlof, George A., Janet L. Yellen, and Michael L. Katz. 1996. An analysis of out-of-wedlock childbearing in the United States. Ouarterlv Iournal of Economics 111, no. 2:277-317.

Alesina, Alberto, and Paola Giuliano. 2006. Divorce, fertility and the shot gun marriage. NBER Working Paper no. 12375, National Bureau of Economic Research, Cambridge, MA.

Argys, Laura M., H. Elizabeth Peters, and Donald M. Waldman. 2001. Can the Family Support Act put some life back into deadbeat dads? An analysis of child-support guidelines, award rates, and levels. Iournal of $H_{u-}$ man Resources 36, no. 2:226-52.

Beller, Andrea H., and John W. Graham. 1991. The effect of child support enforcement on child support payments. Population Research and Policy Review 10, no. 2:91-116.

Bertrand, Marianne, Claudia Goldin, and Lawrence F. Katz. 2010. Dynamics of the gender gap for young professionals in the financial and corporate sectors. American Economic Iournal: Applied Economics 2, no. 3:22855.

Bertrand, Marianne, Emir Kamenica, and Jessica Pan. 2015. Gender identity and relative income within households. Quarterly Iournal of Economics 130, no. 2:571-614.

Bertrand, Marianne, and Jessica Pan. 2013. The trouble with boys: Social influences and the gender gap in disruptive behavior. American Economic Lournal: Applied Economics 5, no. 1:32-64. 
Bharadwaj, Prashant, Katrine Vellesen Loken, and Christopher Neilson. 2013. Early life health interventions and academic achievement. American Economic Reviere 103, no. 5:1862-91.

Browning, Martin, Pierre-Andre Chiappori, and Yoram Weiss. 2014. Economics of the family. Cambridge, MA: Cambridge University Press.

Cancian, Maria, and Daniel R. Meyer. 2005. Effects of the full child support passthrough/disregard on marriage and cohabitation. Report to the Wisconsin Department of Workforce Development, Institute for Research on Poverty.

Case, Anne. 1998. The effects of stronger child support enforcement on non marital fertility. In Fathers under fire: The revolution in child support enforcement, ed. I. Garfinkel, S. McLanahan, D. Meyer, and J. Seltzer, 191214. New York: Russell Sage Foundation.

Case, Anne, Darren Lubotsky, and Christina Paxson. 2002. Economic status and health in childhood: The origins of the gradient. American Economic Review 92, no. 5:1308-34.

Chiappori, Pierre-Andre, and Sonia Oreffice. 2008. Birth control and female empowerment: An equilibrium analysis. Lournal of Political Economv 116, no. 1:113-40.

Chiappori, Pierre-Andre, and Yoram Weiss. 2006. Divorce, remarriage, and welfare: A general equilibrium approach. Lournal of the European Economic Association 4, no. 2/3:415-26.

Committee on Ways and Means, US House of Representatives. 2012. Green book. Washington, DC.

- 2014. Green book. Washington, DC.

Edlund, Lena. 2013. The role of paternity presumption and custodial rights for understanding marriage patterns. Economica 80, no. 320:650-69.

Flood, Sarah, Miriam King, Steven Ruggles, and J. Robert Warren. 2017. Integrated Public Use Microdata Series, Current Population Survey: version 5.0. Data set. Minneapolis, MN: IPUMS, Minneapolis.

Freeman, Richard B., and Jane Waldfogel. 2001. Dunning delinquent dads: The effects of child support enforcement policy on child support receipt by never married women. Lournal of Human Resources 36, no. 2:207-25.

Haas-Wilson, Deborah. 1996. The impact of state abortion restrictions on minors' demand for abortions. Lournal of Human Resources 31, no. 1:14058.

Halvorsen, Thomas, and Jo Jakobsen. 2013. Democrats, Republicans - or both? An empirical analysis of the effects of the composition of state governments on FDI, 1977-2004. International Interactions 2, no. 39:16791.

Henshaw, Stanley, Ted Joyce, Amanda Dennis, Lawrence Finer, and Kelly Blanchard. 2009. Restrictions on Medicaid funding for abortions: A literature review. New York: Guttmacher Institute. 
Henshaw, Stanley, and Kathryn Kost. 2008. Trends in the characteristics of women obtaining abortions, 1974 to 2004. New York: Guttmacher Institute.

Huang, Chien-Chung, Irwin Garfinkel, and Jane Waldfogel. 2004. Child support enforcement and welfare caseloads. Iournal of Human Resources 39, no. 1:108-34.

Jones, Rachel K., and Kathryn Kooistra. 2011. Abortion incidence and access to services in the United States, 2008. Perspectives on Sexual and Reproductive Health 43, no. 1:41-50.

Joyce, Ted, and Robert Kaestner. 2000. The impact of Mississippi's mandatory delay law on the timing of abortion. Family Planning Perspectives 32, no. 1:4-13.

Lerman, Robert I., and Elaine Sorensen. 2003. Child support: Interactions between private and public transfers. In Means-tested transfer programs in the United States, ed. Robert Moffitt. Chicago: University of Chicago Press.

Lichter, Daniel T., Sharon Sassler, and Richard N. Turner. 2014. Cohabitation, post-conception unions, and the rise in nonmarital fertility. Social Science Research 47:134-47.

McLanahan, Sara, and Gary D. Sandefur. 1994. Growing up with a single parent: What hurts, what helps. Cambridge, MA: Harvard University Press.

Meyer, Bruce D., and Nikolas Mittag. 2019. Using linked survey and administrative data to better measure income: Implications for poverty, program effectiveness, and holes in the safety net. American Economic Iournal: Applied Economics 11, no. 2:176-204.

Meyer, Bruce D., Wallace K. C. Mok, and James X. Sullivan. 2015. Household surveys in crisis. Lournal of Economic Perspectives 29, no. 4:199226.

Miller, Cynthia, Irwin Garfinkel, and Sara McLanahan. 1997. Child support in the U.S.: Can fathers afford to pay more? Review of Income and Wealth 43, no. 3:261-81.

Moffitt, R. A. 1998. The effect of welfare on marriage and fertility: What do we know and what do we need to know? Institute for Research on Poverty Discussion Papers no. 1153-97, University of Wisconsin Institute for Research on Poverty.

Plotnick, Robert D., Irwin Garfinkel, Sara S. McLanahan, and Inhoe Ku. 2007. The impact of child support enforcement policy on nonmarital childbearing. Iournal of Policy Analysis and Management 26, no. 1:7998.

Rossin-Slater, Maya. 2017. Signing up new fathers: Do paternity establishment initiatives increase marriage, parental investment, and child wellbeing? American Economic Journal: Applied Economics 9, no. 2:93-130. 
Solomon-Fears, Carmen. 2005. The child support enforcement program: A review of the data. CRS Report no. RL32875, Congressional Research Service.

Sorensen, Elaine, and Ariel Hill. 2004. Single mothers and their childsupport receipt: How well is child-support enforcement doing? Lournal of Human Resources 39, no. 1:135-54.

Stevenson, Betsey, and Justin Wolfers. 2007. Marriage and divorce: Changes and their driving forces. Lournal of Economic Perspectives 21, no. 2:27-52.

US Department of Health and Human Services. 2002. Essentials for attorneys in child support enforcement. 3rd ed.

Wheaton, Laura. 1997. Child support underreporting: A tale of two supplements. Proceedings of the Section on Government Statistics and Section on Social Statistics, American Statistical Association.

Willis, Robert J. 1999. A theory of out-of-wedlock child bearing. Lournal of Political Economv 107 no. S6:S33-S64. 